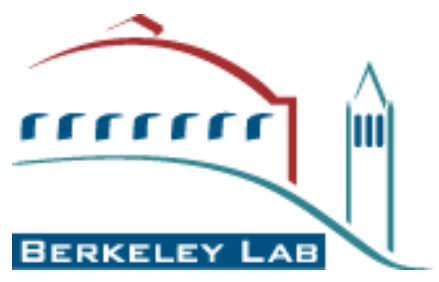

\title{
Self-benchmarking Guide for Laboratory Buildings: Metrics, Benchmarks, Actions
}

\author{
Paul Mathew, Ph.D. \\ Steve Greenberg, P.E. \\ Dale Sartor, P.E. \\ Lawrence Berkeley National Laboratory \\ Berkeley, California
}

Prepared for:

New York State Energy Research and Development Authority

13 July 2009 


\section{Legal Notice}

This report was prepared as a result of work sponsored by the New York State Energy Research and Development Authority (NYSERDA). It does not necessarily represent the views of NYSERDA, their employees, or the State of New York. NYSERDA, the State of New York, and its employees make no warranty, express or implied, and assume no legal liability for the information in this report; nor does any party represent that the use of this information will not infringe upon privately owned rights. This report has not been approved or disapproved by NYSERDA, nor has NYSERDA passed upon the accuracy or adequacy of the information in this report.

\section{Disclaimer}

This document was prepared as an account of work sponsored by the United States Government. While this document is believed to contain correct information, neither the United States Government nor any agency thereof, nor The Regents of the University of California, nor any of their employees, makes any warranty, express or implied, or assumes any legal responsibility for the accuracy, completeness, or usefulness of any information, apparatus, product, or process disclosed, or represents that its use would not infringe privately owned rights. Reference herein to any specific commercial product, process, or service by its trade name, trademark, manufacturer, or otherwise, does not necessarily constitute or imply its endorsement, recommendation, or favoring by the United States Government or any agency thereof, or The Regents of the University of California. The views and opinions of authors expressed herein do not necessarily state or reflect those of the United States Government or any agency thereof or The Regents of the University of California.

\section{Acknowledgements}

This guide leverages and builds on prior research supported by the national Laboratories for the 21st Century (Labs21) program, supported by the U.S. Department of Energy, under Contract No. DE-AC02-05CH11231 and the U.S. Environmental Protection Agency. 


\section{Table of Contents}

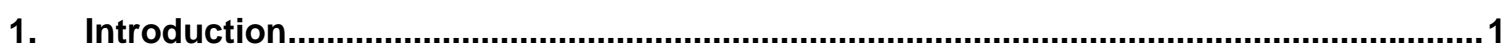

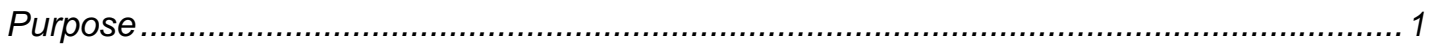

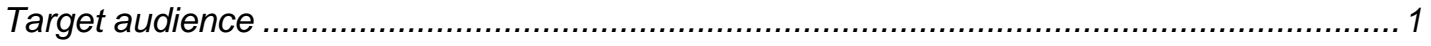

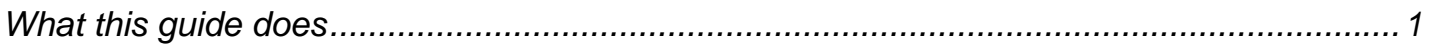

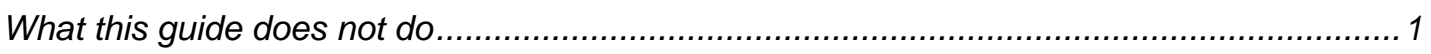

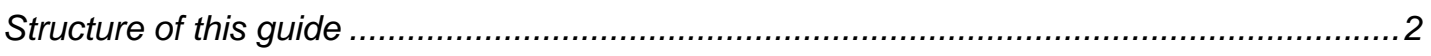

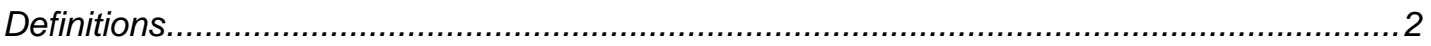

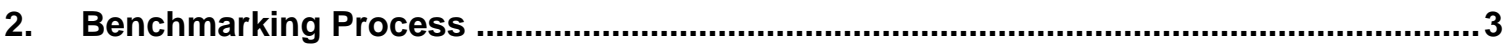

3. Whole Building Performance Metrics $\ldots$

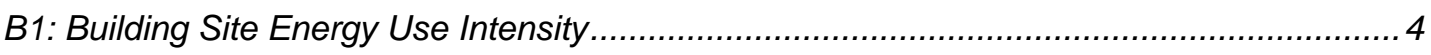

B2: Building Source Energy Use Intensity ................................................................. 5

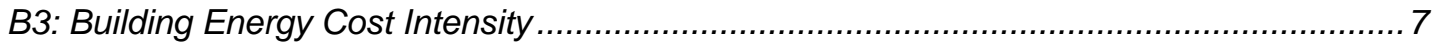

B4: Building Peak Electrical Demand Intensity .......................................................... 9

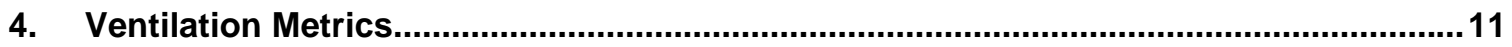

V1: Minimum Laboratory Ventilation Rate: Area-based ..................................................... 11

V2: Minimum Laboratory Ventilation Rate: Volume-based ................................................. 12

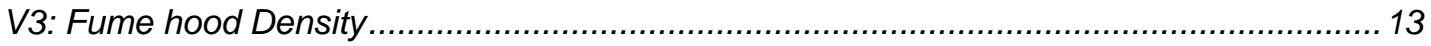

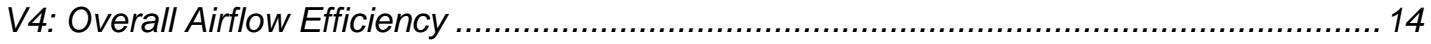

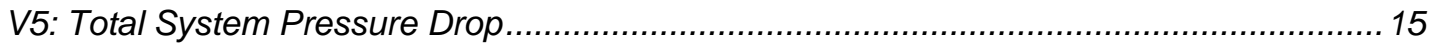

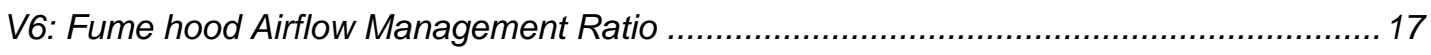

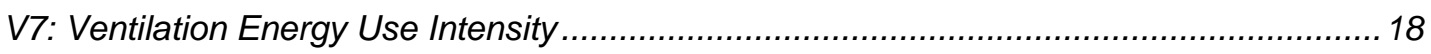

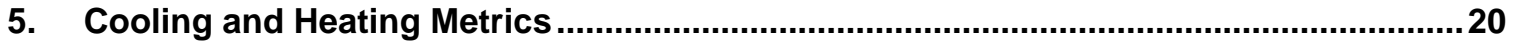

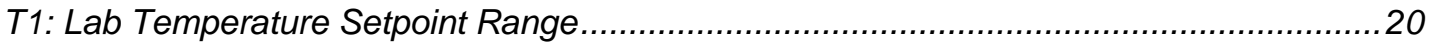

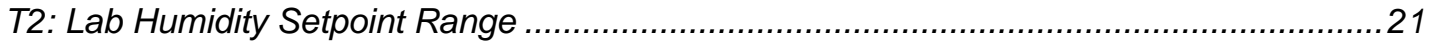

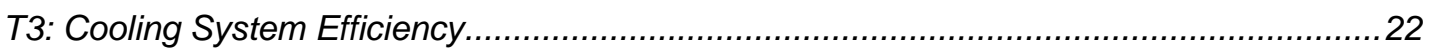

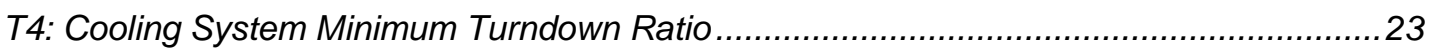

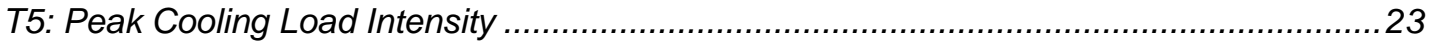

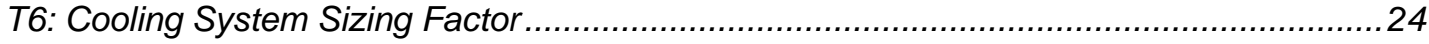

T7: Chilled Water Loop Temperature Differential....................................................... 25

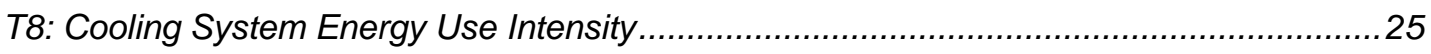

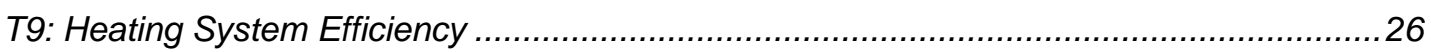

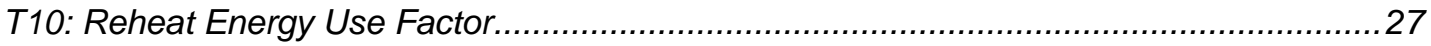

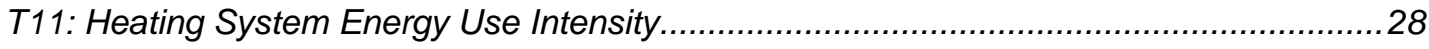




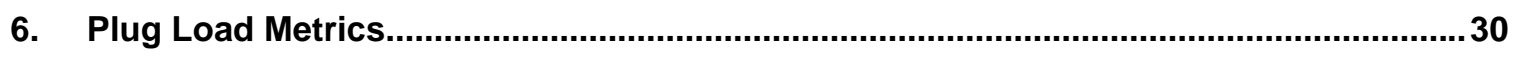

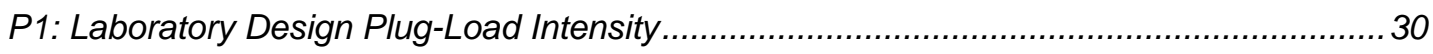

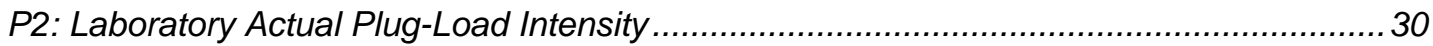

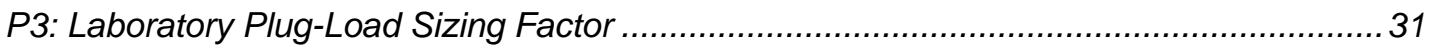

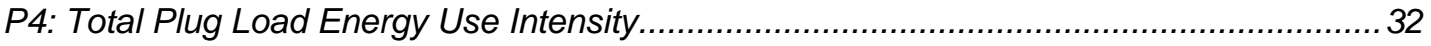

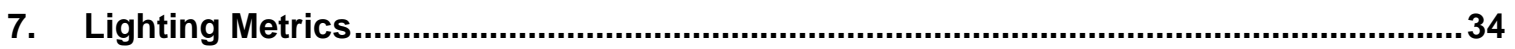

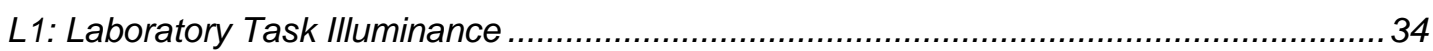

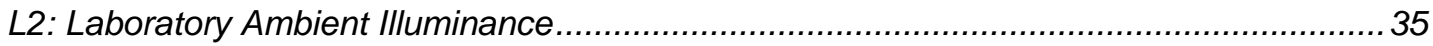

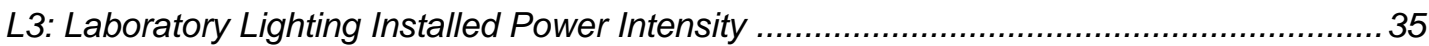

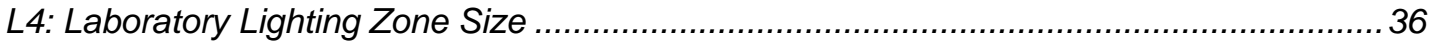

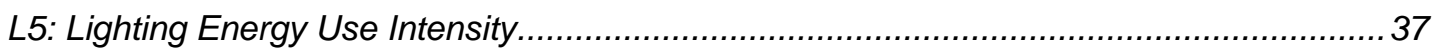

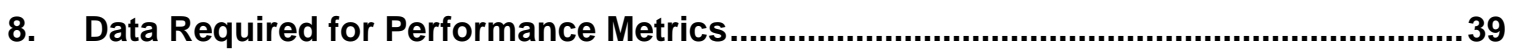

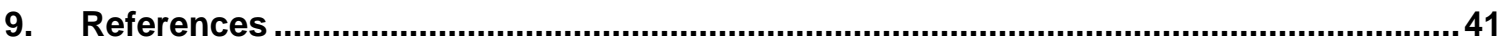




\section{Introduction}

\section{Purpose}

This guide describes energy efficiency metrics and benchmarks that can be used to track the performance of and identify potential opportunities to reduce energy use in laboratory buildings.

\section{Target audience}

This guide is primarily intended for personnel who have responsibility for managing energy use in existing laboratory facilities - including facilities managers, energy managers, and their engineering consultants. Additionally, laboratory planners and designers may also use the metrics and benchmarks described in this guide for goal-setting in new construction or major renovation.

\section{What this guide does}

This guide provides the following information:

- A step-by-step outline of the benchmarking process.

- A set of performance metrics for the whole building as well as individual systems. For each metric, the guide provides a definition, performance benchmarks, and potential actions that can be inferred from evaluating this metric.

- A list and descriptions of the data required for computing the metrics

This guide is complemented by spreadsheet templates for data collection and for computing the benchmarking metrics.

This guide builds on prior research supported by the national Laboratories for the $21 \mathrm{st}$ Century (Labs21) program, supported by the U.S. Department of Energy and the U.S. Environmental Protection Agency. Much of the benchmarking data are drawn from the Labs 21 benchmarking database and technical guides. Additional benchmark data were obtained from engineering experts including laboratory designers and energy managers.

\section{What this guide does not do}

While the energy benchmarking approach describe in this guide can be used to identify potential efficiency opportunities, this guide does not in and of itself constitute an energy audit procedure or checklist. (However, benchmarking may be used as part of an energy audit procedure, or to help prioritize areas for more in-depth audits). The guide does not describe how to calculate savings from the potential actions identified. This guide also does not describe detailed measurement procedures and equipment needed for obtaining the data required to compute metrics. 
Section 2 outlines the benchmarking process and how to use this guide in this context. Users should start here.

Sections 3 through 7 describe the performance metrics and how to use them. A summary of the metrics is provides at the beginning of each section. Users can use these sections as a reference manual, to prioritize which metrics to evaluate, and determine data requirements.

Section 8 provides a list of the data required for computing the metrics and limited guidance on how to obtain the data.

Section 9 lists references.

\section{Definitions}

A Performance Metric is a unit of measure used to assess performance; e.g. Ventilation airflow efficiency (W/cfm), Building Site Energy Intensity (BTU/sf-yr).

A Performance Benchmark is a particular value of the metric that is used as a point of comparison; e.g. $0.6 \mathrm{~W} / \mathrm{cfm}$ may be considered "good practice" for ventilation airflow efficiency. 


\section{Benchmarking Process}

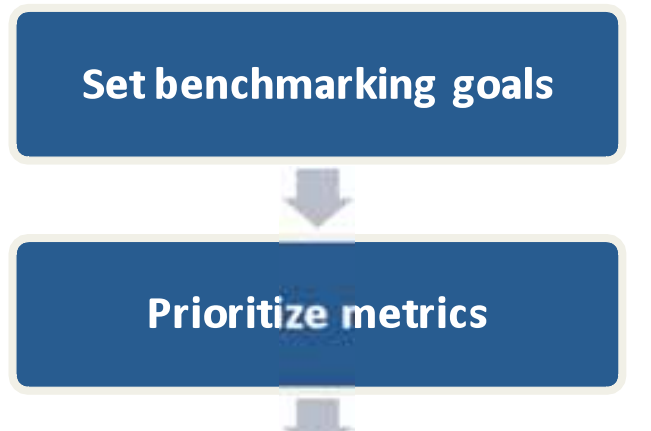

Identify required data and develop data collection plan

\section{Collect data}

\section{Analyze data and compute metrics}

\section{Benchmark metrics and identify potential actions}

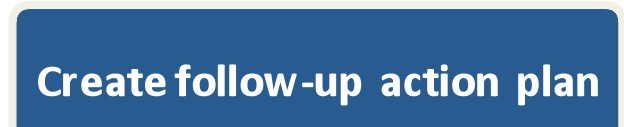

\section{Share results}

- Identify purpose of benchmarking- baselining, identif ying actions, comparison to portf olio, etc.

- Determine extent of $f$ acility and systems to be evaluated.

- Use metrics/data template

- Prioritize based on goals and available resources

- Use metrics/data template

- Identif y source (EMCS, drawings, temporary meters, etc.), measurement period and f requency, responsible person for each data item.

- Utility lending libraries may be good sourcef or monitoring equipment.

- Check equipment and ensure that data is being collected as intended.

- Use spreadsheets and metrics/data template to convert raw data into metrics.

- Compare metrics to benchmark values provided in this guide. Identif y potential actions based on benchmark results.

- Identify which actions can be implemented immediately and which require more detailed audit.

- Share and compare results with peer organizations.

- Add results to benchmarking databases. 


\section{Whole Building Performance Metrics}

\begin{tabular}{|l|l|c|}
\hline ID & Name & Priority \\
\hline B1 & Building Site Energy Use Intensity & 1 \\
\hline B2 & Building Source Energy Use Intensity & 1 \\
\hline B3 & Building Energy Cost Intensity & 2 \\
\hline B4 & Building Peak Electrical Demand Intensity & 2 \\
\hline
\end{tabular}

\section{B1: Building Site Energy Use Intensity}

\section{Description:}

This metric is the sum of the total site energy use per unit of gross building area. This metric is one of the most commonly used whole-building performance metrics, because the data required are usually easy to obtain from utility bills. However, it can be misleading because it does not account for the source energy for each energy stream.

Units: $\mathrm{kBTU} / \mathrm{ft}^{2}\left[\mathrm{kWh} / \mathrm{m}^{2}, \mathrm{MJ} / \mathrm{m}^{2}\right]$

$\mathrm{B} 1=((\mathrm{dE} 1 * 3.412+(\mathrm{dE} 2+\mathrm{dE} 3+\mathrm{dE} 4+\mathrm{dE} 5+\mathrm{dE} 6+\mathrm{dE} 7) * 1000) \div \mathrm{dB} 1$ where:

$\mathrm{dE1}$ : Annual electrical energy use $(\mathrm{kWh})$

dE2: Annual natural gas energy use (Million BTU)

dE3: Annual fuel oil energy use (Million BTU)

dE4: Annual other fuel energy use (Million BTU)

dE5: Annual district steam energy use (Million BTU)

dE6: Annual district hot water energy use (Million BTU)

dE7: Annual district chilled water energy use (Million BTU)

$\mathrm{dB} 1$ : Building gross area $\left(\mathrm{ft}^{2}\right)$

See section 8 for more information on the data items.

\section{Benchmarks:}

This metric can be benchmarked relative to peer buildings in the Labs 21 database. The peer group should be a sub set of buildings in the Labs21 database that have similar characteristics in terms of climate zone, lab type, lab area ratio and occupancy hours. The Labs 21 tool provides guidance on selecting a peer group. 


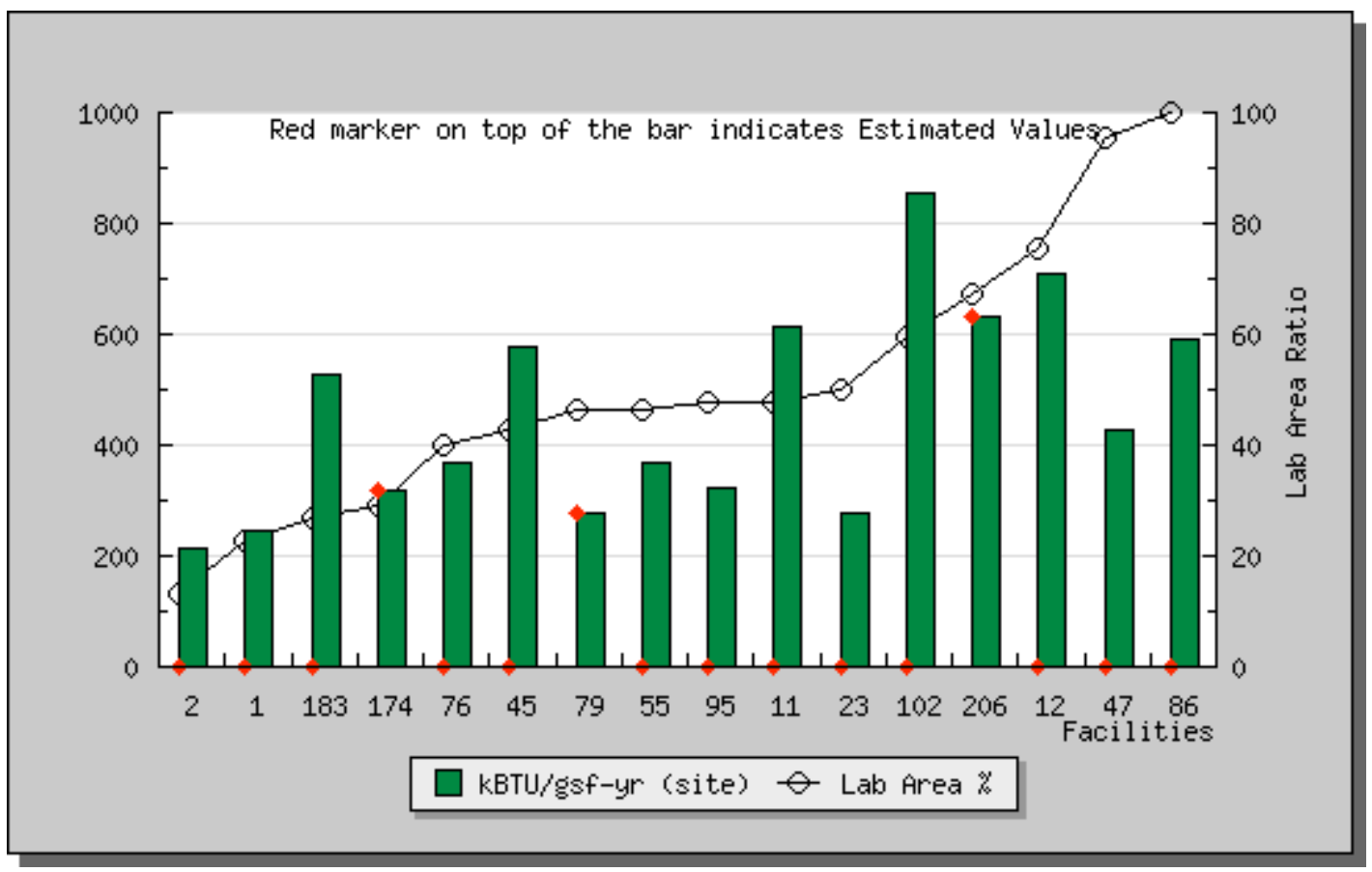

Figure 1. Site energy intensity for a subset of buildings in the Labs21 database, with the following filters applied: located in climate zone 5A (cool humid); lab type: biological, chemical, chemical/biological.

\section{Actions Inferred:}

This metric provides a measure of overall efficiency potential i.e. higher values relative to the peer group suggest higher efficiency potential and vice versa.

\section{Special Considerations:}

This metric is not effective for comparing sites with co-generation, because it does not account for source energy of electricity. Therefore this metric should be complemented with source energy use intensity (B2).

The ability of this metric to identify efficiency potential is limited by the degree to which the peer group of buildings has similar characteristics. While the Labs 21 benchmarking tool allows for simple data filtering of key characteristics (climate zone, lab area ratio, lab type, occupancy hours), there may be other characteristics (e.g. process loads) that cause energy use to be higher or lower independent of efficiency. Therefore, this metric is only a coarse screen for overall efficiency potential.

\section{B2: Building Source Energy Use Intensity}

\section{Description:}

This metric is the sum of the total source energy use per unit of gross building area.

Units: $\mathrm{kBTU} / \mathrm{ft}^{2}\left[\mathrm{kWh} / \mathrm{m}^{2}, \mathrm{MJ} / \mathrm{m}^{2}\right]$

$$
\begin{aligned}
& \mathrm{B} 2=((\mathrm{dE} 1 * 3.412 * \mathrm{SFe}+(\mathrm{dE} 2 * \mathrm{SFn}+\mathrm{dE} 3 * \mathrm{SFf}+\mathrm{dE} 4 * \mathrm{SFo}+\mathrm{dE} 5 * \mathrm{SFs}+\mathrm{dE} 6 * \mathrm{SFh}+ \\
& \mathrm{dE} 7 * \mathrm{SFc}) * 1000) \div \mathrm{dB} 1
\end{aligned}
$$


where:

dE1: Annual electrical energy use (kWh)

dE2: Annual natural gas energy use (Million BTU)

dE3: Annual fuel oil energy use (Million BTU)

dE4: Annual other fuel energy use (Million BTU)

dE5: Annual district steam energy use (Million BTU)

dE6: Annual district hot water energy use (Million BTU)

dE7: Annual district chilled water energy use (Million BTU)

$\mathrm{dB} 1$ : Building gross area $\left(\mathrm{ft}^{2}\right)$

SFe: Source factor for electricity (BTU/BTU)

SFn: Source factor for natural gas (BTU/BTU)

SFf: Source factor for fuel oil (BTU/BTU)

SFo: Source factor for other fuels (BTU/BTU)

SFs: Source factor for district steam (BTU/BTU)

SFh: Source factor for district hot water (BTU/BTU)

SFc: Source factor for district chilled water (BTU/BTU)

See section 8 for more information on the data items dE1-dE7 and dB1.

The following typical values for source factors are used in the Energy Star Portfolio Manager tool (see as well the Labs21 benchmarking tool.

\begin{tabular}{|l|l|}
\hline Energy Stream & Source Factor \\
\hline Electricity & 3.34 \\
\hline Natural gas & 1.047 \\
\hline Fuel Oil & 1.01 \\
\hline Other fuels & 1.0 \\
\hline District Chilled water & 1.05 \\
\hline District hot water & 1.35 \\
\hline District steam & 1.45 \\
\hline
\end{tabular}

\section{Benchmarks:}

This metric can be benchmarked relative to peer buildings in the Labs 21 database. The peer group should be a sub set of buildings in the Labs21 database that have similar characteristics in terms of climate zone, lab type, lab area ratio and occupancy hours. The Labs 21 tool provides guidance on selecting a peer group. 


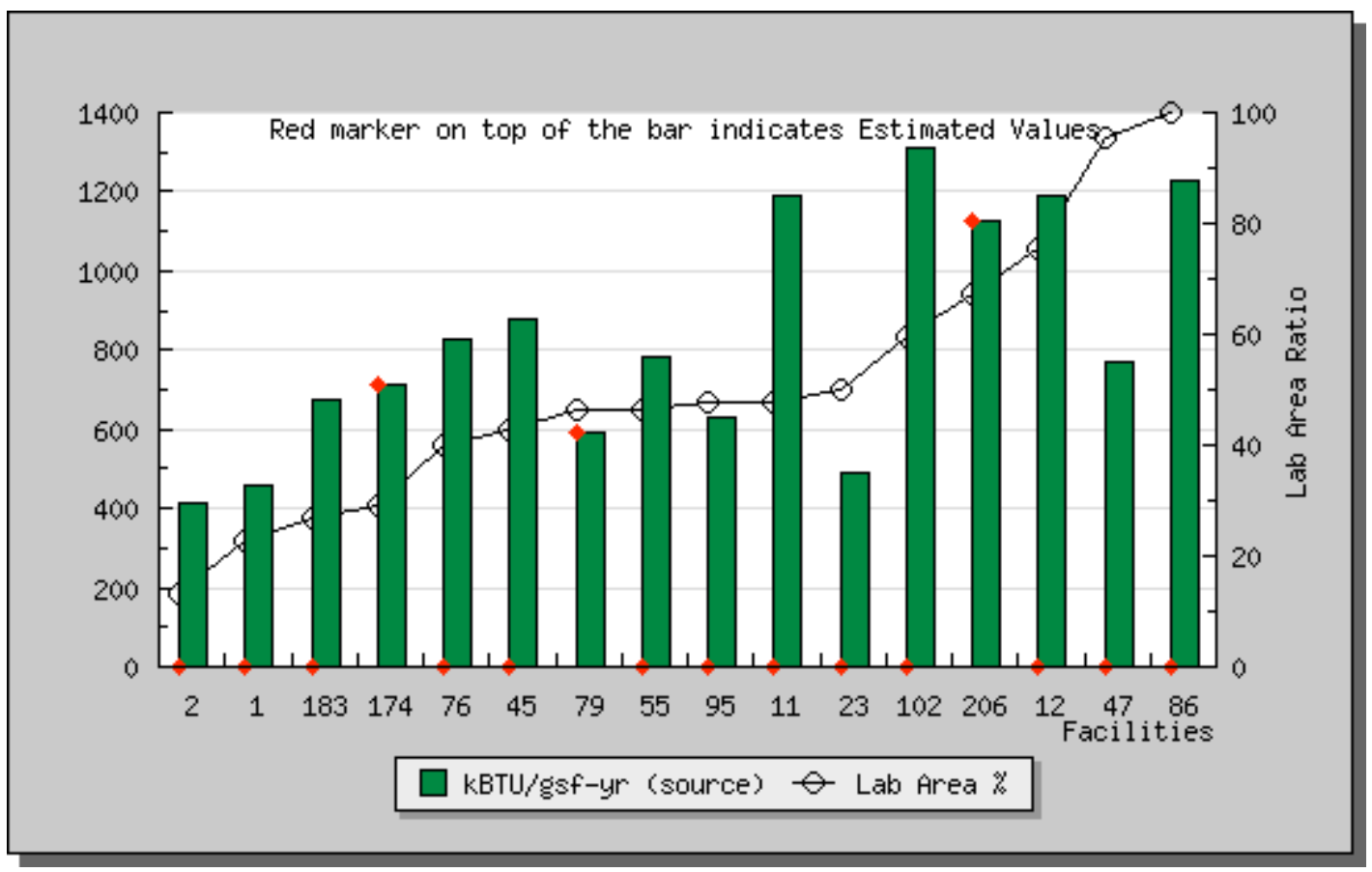

Figure 2. Source energy intensity for a subset of buildings in the Labs21 database, with the following filters applied: located in climate zone 5A (cool humid); lab type: biological, chemical, chemical/biological;

\section{Actions Inferred:}

This metric provides a measure of overall efficiency potential i.e. higher values relative to the peer group suggest higher efficiency potential and vice versa.

\section{Special Considerations:}

The ability of this metric to identify efficiency potential is limited by the degree to which the peer group of buildings has similar characteristics. While the Labs 21 benchmarking tool allows for simple data filtering of key characteristics (climate zone, lab area ratio, lab type, occupancy hours), there may be other characteristics (e.g. process loads) that cause energy use to be higher or lower independent of efficiency. Therefore, this metric is only a coarse screen for overall efficiency potential.

\section{B3: Building Energy Cost Intensity}

\section{Description:}

This metric is the sum of all energy costs use per unit of gross building area.

Units: $\$ / \mathrm{ft}^{2}\left[\right.$ Currency $\left./ \mathrm{m}^{2}\right]$

$\mathrm{B} 3=\mathrm{dE} 6 \div \mathrm{dB} 1$

where:

dE6: Annual energy cost (\$)

$\mathrm{dB} 1$ : Building gross area $\left(\mathrm{ft}^{2}\right)$

See section 8 for more information on the data items. 


\section{Benchmarks:}

This metric can be benchmarked relative to peer buildings in the Labs 21 database. The peer group should be a sub set of buildings in the Labs21 database that have similar characteristics in terms of climate zone, lab type, lab area ratio and occupancy hours. The Labs21 tool provides guidance on selecting a peer group.

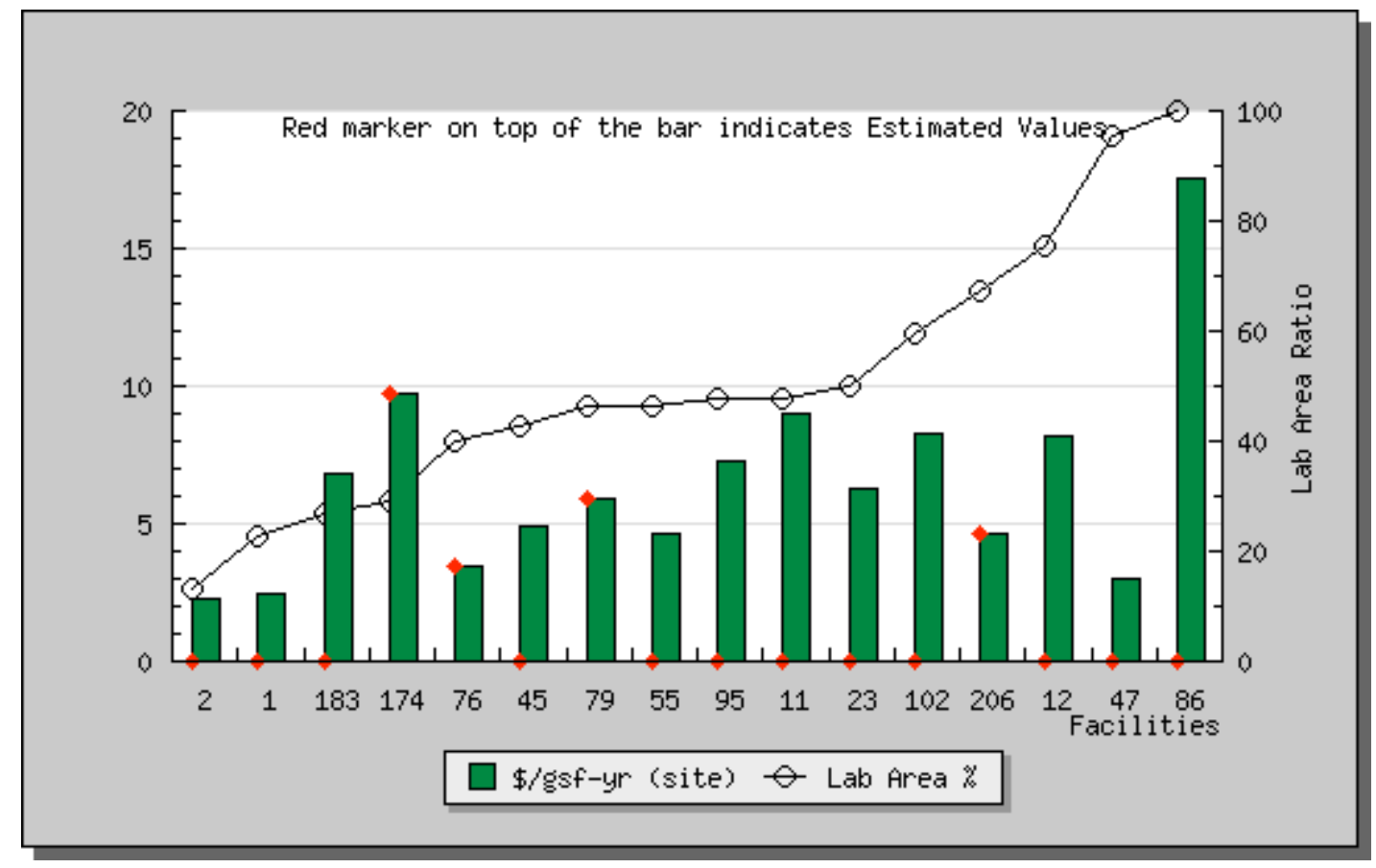

Figure 3. Energy cost intensity for a subset of buildings in the Labs21 database, with the following filters applied: located in climate zone 5A (cool humid); lab type: biological, chemical, chemical/biological;

\section{Actions Inferred:}

This metric provides a measure of overall cost reduction potential i.e. higher values relative to the peer group suggest higher potential to reduce costs and vice versa. Costs can be reduced by either reducing energy use or procuring energy at lower per-unit cost.

\section{Special Considerations:}

Note that energy cost is a function of energy use, unit cost of energy, demand charges, and other utility charges that may not be directly related to energy use. Therefore, this metric is not a good indicator of energy efficiency potential i.e. a low-energy use building may have high energy costs because of high unit costs of energy.

As in the case of metrics B1 and B2, the ability of this metric to identify savings potential is limited by the degree to which the peer group of buildings has similar characteristics. While the Labs 21 benchmarking tool allows for simple data filtering of key characteristics (climate zone, lab area ratio, lab type, occupancy hours), there may be other characteristics (e.g. process loads) that cause energy use to be higher or lower independent of efficiency. Therefore, this metric is only a coarse screen for overall efficiency potential. 


\section{Description:}

This metric is the peak electrical per unit of gross building area.

Units: $\mathrm{W} / \mathrm{ft}^{2}\left[\mathrm{~W} / \mathrm{m}^{2}\right]$

$\mathrm{B} 4=\mathrm{dE} 7 * 1000 \div \mathrm{dB} 1$

where:

dE7: Peak electrical demand $(\mathrm{kW})$

$\mathrm{dB1}$ : Building gross area $\left(\mathrm{ft}^{2}\right)$

See section 8 for more information on the data items.

\section{Benchmarks:}

This metric can be benchmarked relative to peer buildings in the Labs 21 database. The peer group should be a sub set of buildings in the Labs21 database that have similar characteristics in terms of climate zone, lab type, lab area ratio and occupancy hours. The Labs21 tool provides guidance on selecting a peer group.

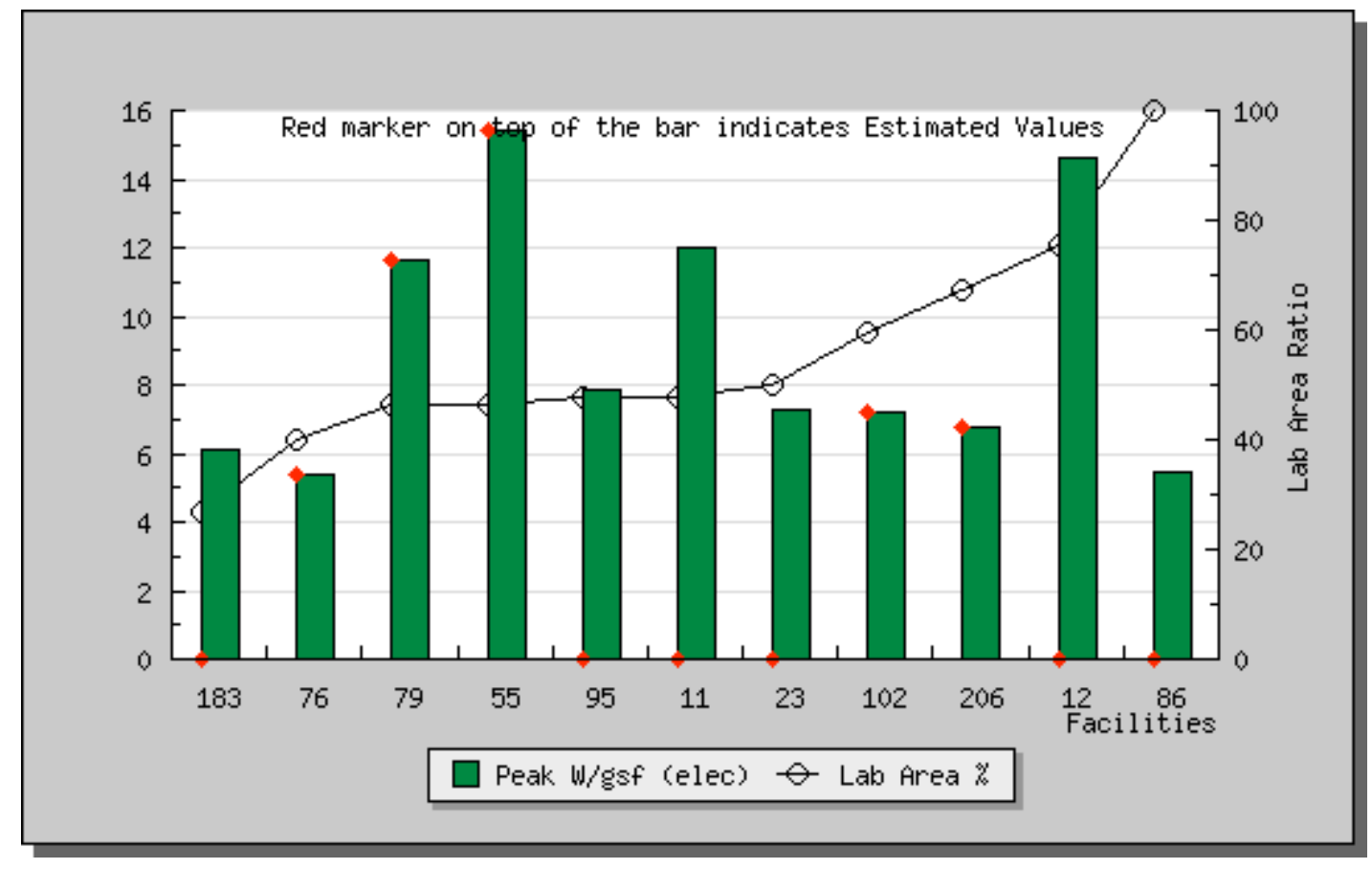

Figure 4. Peak electrical demand intensity for a subset of buildings in the Labs21 database, with the following filters applied: located in climate zone 5A (cool humid); lab type: biological, chemical, chemical/biological;

\section{Actions Inferred:}

This metric provides a measure of overall demand reduction potential i.e. higher values relative to the peer group suggest higher potential to reduce demand and vice versa. 


\section{Special Considerations:}

Note that depending on whether the facility is served by district utilities, the peak demand may or may not include demand due to electric chillers, etc. Therefore, this metric is only a coarse screen for overall demand reduction potential.

As in the case of metrics B1 and B2, the ability of this metric to identify savings potential is limited by the degree to which the peer group of buildings has similar characteristics. While the Labs21 benchmarking tool allows for simple data filtering of key characteristics (climate zone, lab area ratio, lab type, occupancy hours), there may be other characteristics (e.g. process loads) that cause energy use to be higher or lower independent of efficiency. 


\section{Ventilation Metrics}

\begin{tabular}{|c|l|c|}
\hline ID & Name & Priority \\
\hline V1 & Min Laboratory Ventilation Rate: Area-based & 1 \\
\hline V2 & Min Laboratory Ventilation Rate: Volume-based & 1 \\
\hline V3 & Fumehood Density & 2 \\
\hline V4 & Overall Airflow Efficiency (sup\&exh W/ sup\&exh cfm) & 1 \\
\hline V5 & Total System Pressure Drop & 1 \\
\hline V6 & Fumehood Sash Mgmt (avg cfm/min cfm) & 1 \\
\hline V7 & Ventilation Energy Use Intensity & 3 \\
\hline
\end{tabular}

\section{V1: Minimum Laboratory Ventilation Rate: Area-based}

\section{Description:}

This metric is the minimum amount of outside air per unit of net laboratory area. In most laboratories, this metric is driven by the minimum ventilation rate required for health and safety. The only exceptions to this are laboratories where the air change rates are driven by thermal loads (and hence always exceed minimum ventilation rates for health and safety) or where very high fume hood density, typically greater than $1 \mathrm{ft}^{2}$ of hood work surface per 25 $\mathrm{ft}^{2}$ of laboratory, drives the minimum flow.

Units: $\mathrm{cfm} / \mathrm{ft}^{2}\left[1 / \mathrm{s}-\mathrm{m}^{2}\right]$

$$
\mathrm{V} 1=\mathrm{dV} 1 \div \mathrm{dB} 2
$$

where:

dV1: Laboratory Supply Airflow Min (cfm)

$\mathrm{dB} 2$ : Laboratory area (net $\mathrm{ft}^{2}$ )

See section 8 for more information on the data items.

\section{Benchmarks:}

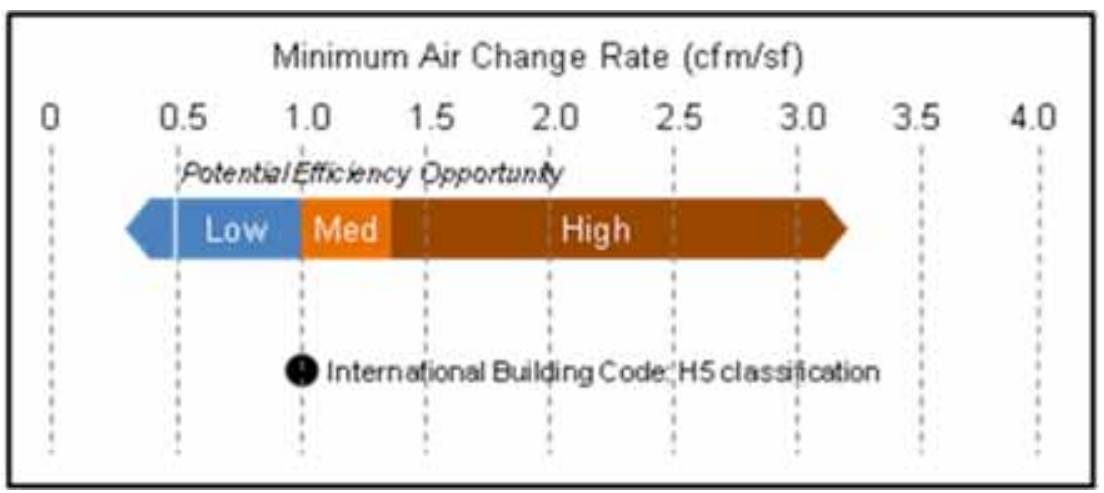

Figure 5. Benchmarks area-based minimum ventilation rates 


\section{Actions Inferred:}

- For general exhaust driven labs: Optimize health and safety mandated minimum space ventilation rate

- For fume hood driven labs: Lower the minimum airflow rate through fume hoods either through better sash management (see metric V6) or by using fume hoods that have the capability to reduce airflow to $25 \mathrm{cfm} / \mathrm{sf}$ of work surface when not in use.

- For thermal load driven labs: Provide separate thermal conditioning such that the minimum ventilation rate is not driven by thermal loads.

\section{V2: Minimum Laboratory Ventilation Rate: Volume-based}

\section{Description:}

This metric is the minimum amount of outside air expressed in air changes per hour. It is more commonly used than the area-based metric (V1). In most laboratories, this metric is driven by the minimum ventilation rate required for health and safety. The only exceptions to this are laboratories where the air change rates are driven by thermal loads (and hence always exceed minimum ventilation rates for health and safety) or where very high fume hood density, typically greater than $1 \mathrm{ft}^{2}$ of hood work surface per $25 \mathrm{ft}^{2}$ of laboratory, drives the minimum flow.

Units: $\mathrm{ACH}\left[\mathrm{hr}^{-1}\right]$

$\mathrm{V} 2=\mathrm{dV} 1 * 60 \div \mathrm{dB} 3$

where:

dV1: Laboratory Supply Airflow Min [cfm]

$\mathrm{dB} 3$ : Laboratory volume [net $\mathrm{ft}^{3}$ ]

See section 8 for more information on the data items.

\section{Benchmarks:}

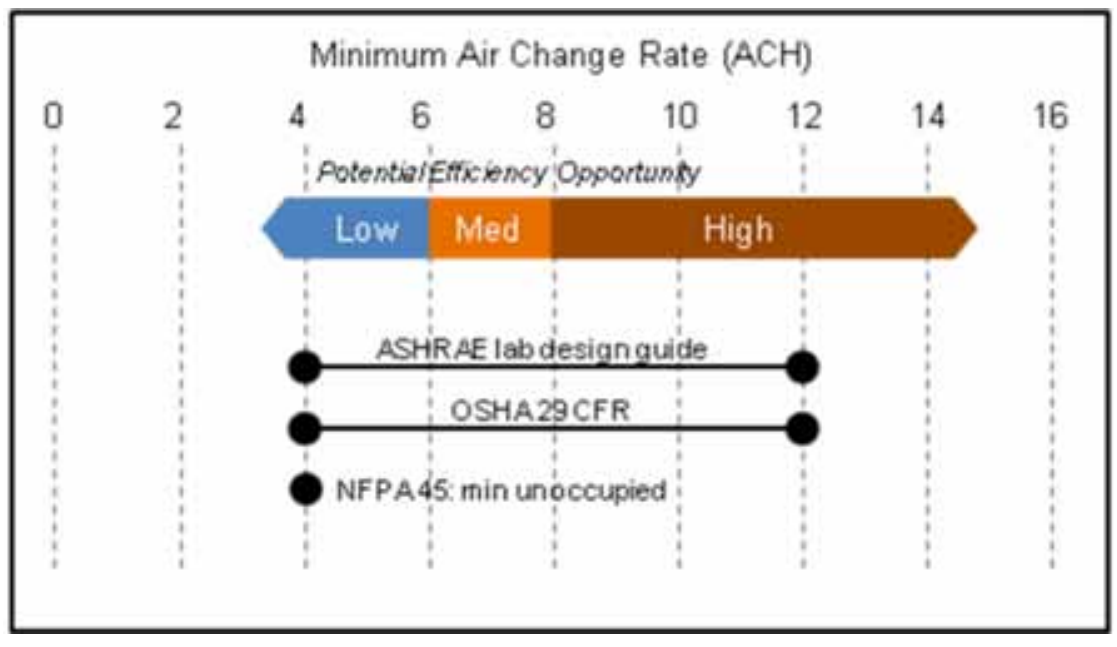

Figure 6. Benchmarks for minimum air change rates 


\section{Actions Inferred:}

- For general exhaust driven labs: Optimize health and safety mandated minimum space ventilation rate

- For fume hood driven labs: Lower the minimum airflow rate through fume hoods either through better sash management (see metric V6) or by using fume hoods that have the capability to reduce airflow to $25 \mathrm{cfm} / \mathrm{sf}$ of work surface when not in use.

- For thermal load driven labs: Provide separate thermal conditioning such that the minimum ventilation rate is not driven by thermal loads.

\section{Special Considerations:}

This metric should be considered alongside the area-based air change rate (V1). Some laboratory professionals believe that V1 more appropriate metric than V2, given that laboratory hazards are more related to floor area than volume i.e. a laboratory with a high ceiling does not necessarily require more ventilation.

\section{V3: Fume hood Density}

\section{Description:}

Number of fume hoods per unit of net laboratory area.

Units: \#/1000ft ${ }^{2}\left[\# / 1000 \mathrm{~m}^{2}\right]$

$$
\mathrm{V} 3=\mathrm{dB} 6 * 1000 \div \mathrm{dB} 2
$$

where:

dB6: Fume hood count [cfm]

$\mathrm{dB} 2$ : Laboratory area $\left[\right.$ net $\left.\mathrm{ft}^{2}\right]$

See section 8 for more information on the data items.

\section{Benchmarks:}

The number of fume hoods is driven by the functional needs of work conducted in the laboratory. Since this can vary widely across different laboratories, it is difficult to define benchmarks. As a point of reference, the chart below shows fume hood density data in various laboratories from the University of California and California State University campuses. Note that these data are based on gross building area, since laboratory area was not available for many of these facilities. 


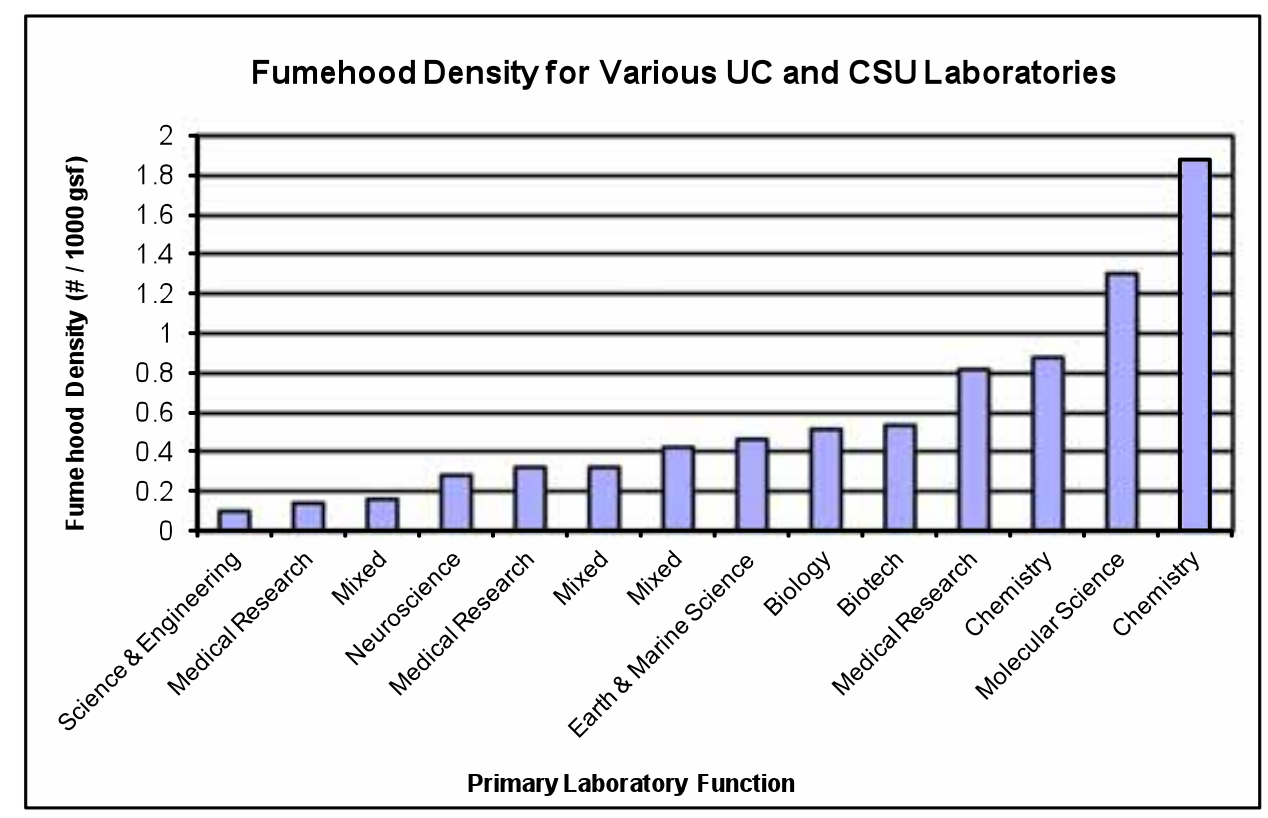

Figure 7. Fumehood density (\#/1000 gross sf) for selected academic laboratories across the University of California and California State University. Data source: UC/CSU/IOU Monitoringbased Commissioning Program.

\section{Actions Inferred:}

- Decommission or remove fume hoods that are no longer required for meeting programmatic requirements.

- Encourage fume hood sharing.

- Use lower-energy alternatives such as snorkels, balance hoods, and chemical storage cabinets where appropriate.

\section{V4: Overall Airflow Efficiency}

\section{Description:}

This metric characterizes overall airflow efficiency in terms of the total fan power required per unit of airflow. This metric provides an overall measure of how efficiently air is moved through the laboratory, from inlet to exhaust, and takes into account low pressure drop design as well as fan system efficiency.

Units: W/cfm $\left[\mathrm{W} / 1-\mathrm{s}^{-1}\right]$

$\mathrm{V} 4=(\mathrm{dV} 2+\mathrm{dV} 3)^{*} 1000 \div(\mathrm{dV} 4+\mathrm{dV} 5)$

where:

dV2: Supply Side Fan Peak Power (kW)

dV3: Exhaust Side Fan Peak Power (kW)

dV4: Supply Side Fan Peak Airflow (cfm)

dV5: Exhaust Side Fan Peak Airflow (cfm)

See section 8 for more information on the data items. 


\section{Benchmarks:}

This metric can be benchmarked relative to peer buildings in the Labs 21 database. The peer group should be a sub set of buildings in the Labs21 database that have similar characteristics in terms of lab type and lab area ratio. This metric is largely not climate driven. Lower values imply more efficient airflow.

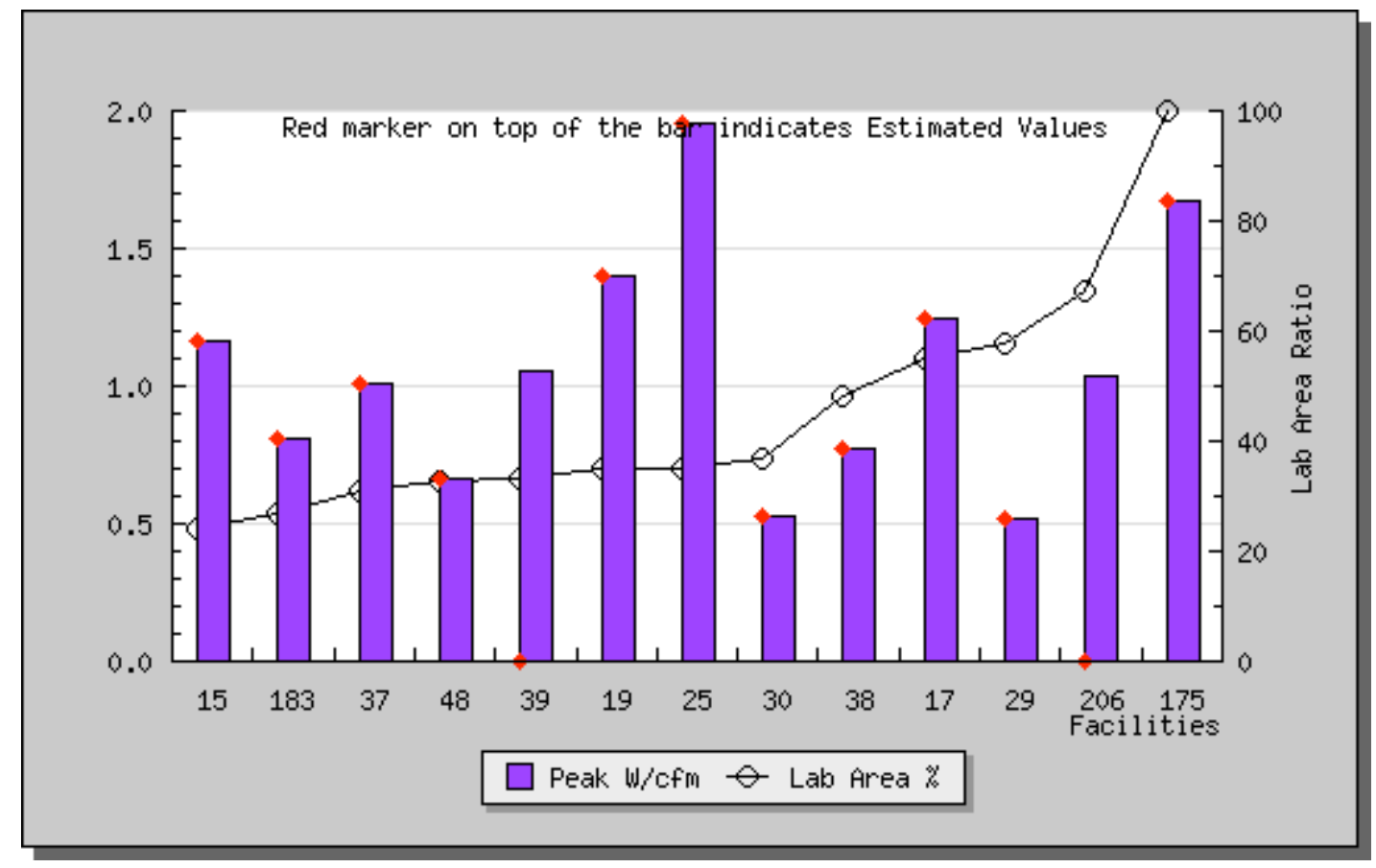

Figure 8. Airflow efficiency for a subset of buildings in the Labs21 database, with the following filters applied: lab type: biological, chemical, chemical/biological

\section{Actions Inferred:}

Airflow efficiency is typically the most significant way to influence overall lab efficiency. There are two major actions that can be taken to improve airflow efficiency:

- Reduce system pressure drop by removing or changing components (e.g. excessive/dirty filters, excessive sound attenuators).

- Improve fan system efficiency by retrofitting motors, belts, drives.

\section{V5: Total System Pressure Drop}

\section{Description:}

This metric is the sum of the supply side pressure drop (from fan to room) and exhaust side pressure drop (from room to exhaust stack). It is a key determinant of overall airflow efficiency and overall ventilation energy use intensity.

Units: in. w.g [Pa]

$$
\mathrm{V} 5=\mathrm{dV} 6+\mathrm{dV} 7
$$

where: 
dV6: Supply-side Pressure Drop (in. w.g.)

dV7: Exhaust-side Pressure Drop (in. w.g.)

See section 8 for more information on the data items.

\section{Benchmarks:}

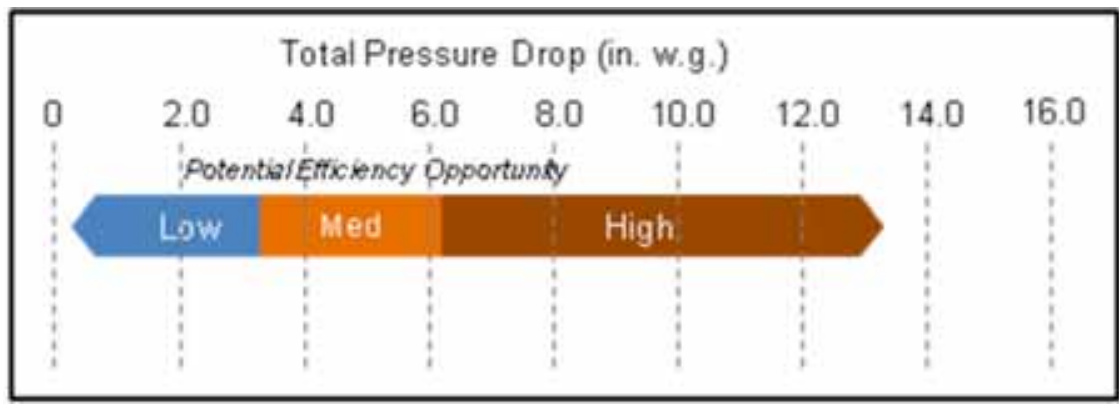

Figure 9. Benchmarks for total system pressure drop.

The benchmarks in figure are based on the component pressure drop benchmarks shown in figure below, as published in an ASHRAE Journal article.

\begin{tabular}{|c|c|c|c|}
\hline Component & Standard & Good & Better \\
\hline Air handler face velocity & 500 & 400 & 300 \\
\hline Air Handler & 2.5 in. w.g. & 1.5 in. w.g. & 0.75 in.w.g. \\
\hline Heat Recovery Device & 1.00 in. w.g. & 0.60 in. w.g. & 0.35 in. w.g. \\
\hline VAV Control Devices & Constant Volume, N/A & $\begin{array}{l}\text { Flow M easurement Devices, } \\
0.60-0.30 \text { in. w.g. }\end{array}$ & $\begin{array}{l}\text { Pressure Differential } \\
\text { Measurement and } \\
\text { Control, } 0.10 \text { in. W.g. }\end{array}$ \\
\hline $\begin{array}{l}\text { Zone Temperature } \\
\text { Control Coils }\end{array}$ & 0.5 in. w.g. & 0.30 in. w.g. & 0.05 in. w.g. \\
\hline $\begin{array}{l}\text { Total Supply and } \\
\text { Return Ductwork }\end{array}$ & 4.0 in. w.g. & 2.25 in. w.g. & 1.2 in. w.g. \\
\hline $\begin{array}{l}\text { Exhaust Stack CFM } \\
\text { and }\end{array}$ & $\begin{array}{l}0.7 \mathrm{~W} \text { w.g. full design flow } \\
\text { through entire exhaust } \\
\text { system, Constant Volume }\end{array}$ & $\begin{array}{l}0.7^{\prime \prime} \text { w.g. full design flow } \\
\text { through fan and stack only, } \\
\text { VAV System with bypass }\end{array}$ & $\begin{array}{l}0.75^{\prime \prime} \text { w.g. averaging } \\
\text { half the design flow, } \\
\text { VAV System with } \\
\text { multiple stacks }\end{array}$ \\
\hline $\begin{array}{l}\text { Noise Control } \\
\text { (Silencers) }\end{array}$ & 1.0" w.g. & $0.25 " \mathrm{w} . \mathrm{g}$ & $0.0^{\prime \prime} \mathrm{w} . \mathrm{g}$. \\
\hline Total & $9.7 "$ w.g. & 6.2" w.g. & $3.2 " \mathrm{w} . \mathrm{g}$ \\
\hline
\end{tabular}

Figure 10. Laboratory component pressure drop benchmarks. Source: Weale, P. Rumsey, D. Sartor, L. E. Lock, "Laboratory Low-Pressure Drop Design," ASHRAE Journal, August 2002

\section{Actions Inferred:}

- Reduce system pressure drop by removing or changing components (e.g. excessive/dirty filters, excessive sound attenuators). 


\section{Description:}

This metric is the ratio of the average flow to the minimum flow i.e. the flow through the fume hood when the sash is closed. Note that this metric is not applicable to constant volume fume hoods (which do not vary the airflow with sash position).

Units: - (unitless)

$$
\begin{aligned}
& \text { V6 }=\mathrm{dV} 8 \div \mathrm{dV} 9 \\
& \text { where: } \\
& \text { dV8: Fume hood Average Airflow (cfm) } \\
& \text { dV9: Fume hood Minimum Airflow (cfm) }
\end{aligned}
$$

See section 8 for more information on the data items.

\section{Benchmarks:}

The benchmarks are based on the following scenario: For a typical 6-ft fume hood, minimum airflow is usually about $300 \mathrm{cfm}$, which corresponds to the NFPA-45 mandated minimum of $25 \mathrm{cfm} / \mathrm{ft}^{2}$ of work surface area. A typical 6-ft fume hood with an 18" sash-stop operates at about $900 \mathrm{cfm}$. Therefore, if the sash were never closed, the airflow management ratio would be 3. Assuming fume hoods are on 24 hours a day, but in actual use only 4 hours, the airflow management ratio with ideal sash management (i.e. sashes always closed when not in use) will be 1.33 i.e. $(300 * 20 \div 24+900 * 4 \div 24) \div 300$.

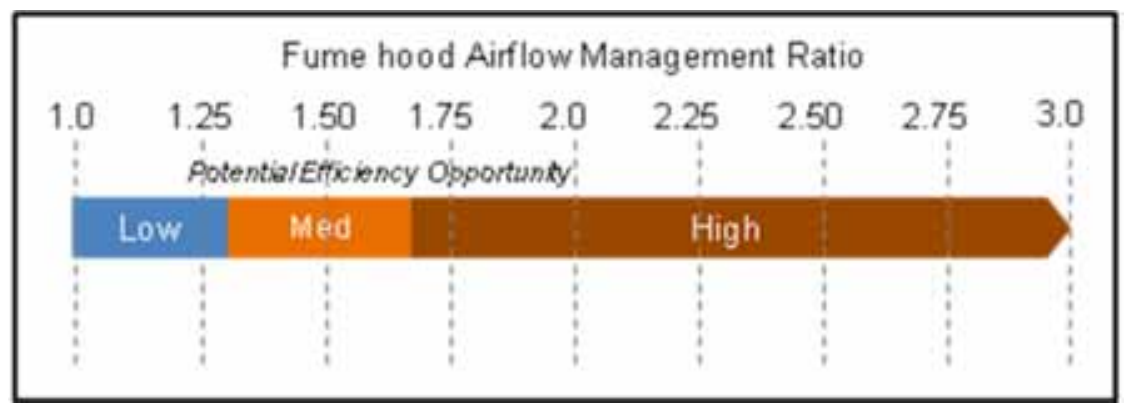

Figure 11. Benchmarks for fume hood airflow management ratio

\section{Actions Inferred:}

A high value of this metric suggests that the fume hood sashes are not being closed when not in use. Sash management can be improved in the following ways:

- User training and awareness.

- Occupancy-based automated sash management.

\section{Special Considerations:}

The benchmark values for this metric assume that:

- Maximum flow is 3 times minimum flow

- Fume hoods are on 24 hours a day but in actual use only 4 hours a day.

If fume hoods are used significantly more than 4 hours per day, the threshold values should be increased and vice versa. If the maximum flow is significantly more than 3 times minimum flow, the threshold values should be increased and vice versa. The potential 
efficiency opportunity for sash management depends on how much time the fume hoods are in actual use.

\section{V7: Ventilation Energy Use Intensity}

\section{Description:}

This metric is the annual ventilation energy use per unit of gross building area.

Units: $\mathrm{kWh} / \mathrm{ft}^{2}\left[\mathrm{kWh} / \mathrm{m}^{2}\right]$

$\mathrm{V} 7=\mathrm{dV} 10 \div \mathrm{dB} 1$

where:

dV10: Ventilation Annual Energy Use (kWh)

$\mathrm{dB} 1$ : Building gross area $\left(\mathrm{ft}^{2}\right)$

See section 8 for more information on the data items.

\section{Benchmarks:}

This metric can be benchmarked relative to peer buildings in the Labs 21 database. The peer group should be a sub set of buildings in the Labs 21 database that have similar characteristics in terms of lab type, lab area ratio and occupancy hours. For buildings in which the airflow is driven by thermal loads, climate zone should also be used as a filter.

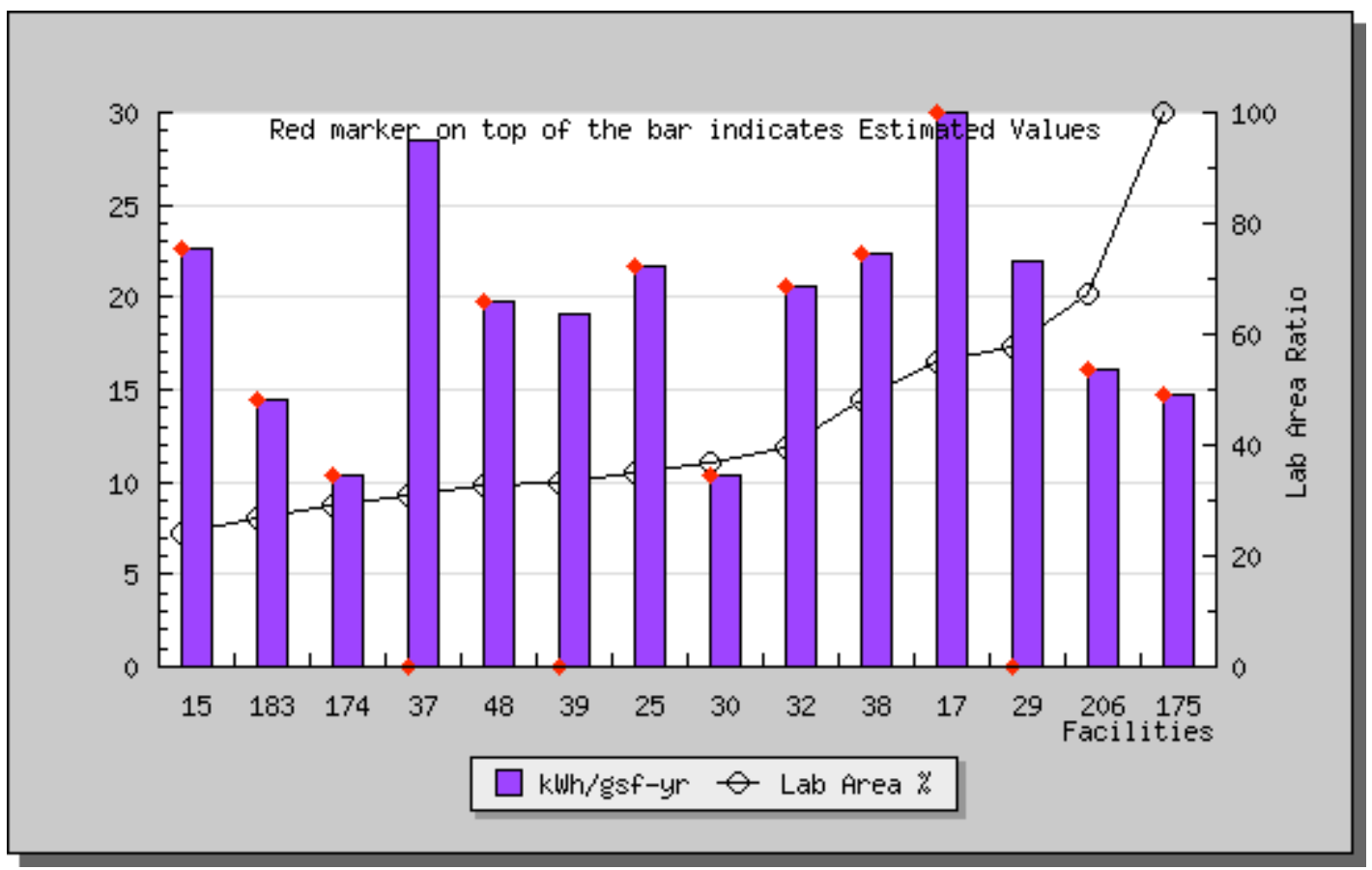

Figure 12. Ventilation energy use intensity for a subset of buildings in the Labs21 database, with the following filters applied: lab type: biological, chemical, chemical/biological;

Actions Inferred: 
This metric provides a measure of overall potential for reducing ventilation energy use i.e. higher values relative to the peer group suggest higher potential to reduce energy use and vice versa.

Special Considerations:

The ability of this metric to identify savings potential is limited by the degree to which the peer group of buildings has similar characteristics. While the Labs 21 benchmarking tool allows for simple data filtering of key characteristics (climate zone, lab area ratio, lab type, occupancy hours), there may be other characteristics (e.g. unusual process loads, high hazards requiring higher air change rates) that cause ventilation energy use to be higher or lower independent of efficiency. 


\section{Cooling and Heating Metrics}

\begin{tabular}{|l|l|c|}
\hline ID & Name & Priority \\
\hline T1 & Lab Temperature Setpoint Range & 1 \\
\hline T2 & Lab Humidity Setpoint Range & 1 \\
\hline T3 & Cooling System Efficiency & 1 \\
\hline T4 & Chiller System Minimum Turndown Ratio & 1 \\
\hline T5 & Peak Cooling Load & 2 \\
\hline T6 & Cooling System Sizing Factor (Installed vs. Peak tons) & 2 \\
\hline T7 & Chilled Water Loop Temp Differential & 2 \\
\hline T8 & Cooling System Energy Use Intensity & 3 \\
\hline T9 & Heating System Efficiency & 1 \\
\hline T10 & Reheat Energy Use Factor & 1 \\
\hline T11 & Heating System Energy Use Intensity & 3 \\
\hline
\end{tabular}

\section{T1: Lab Temperature Setpoint Range}

\section{Description:}

This metric is the range between the heating setpoint and the cooling setpoint.

Units: $\mathrm{F}[\mathrm{C}]$

T1: dT1-dT2 (range)

where:

dT1: Heating setpoint $(\mathrm{F})$

dT2: Cooling setpoint (F)

See section 8 for more information on the data items.

\section{Benchmarks:}

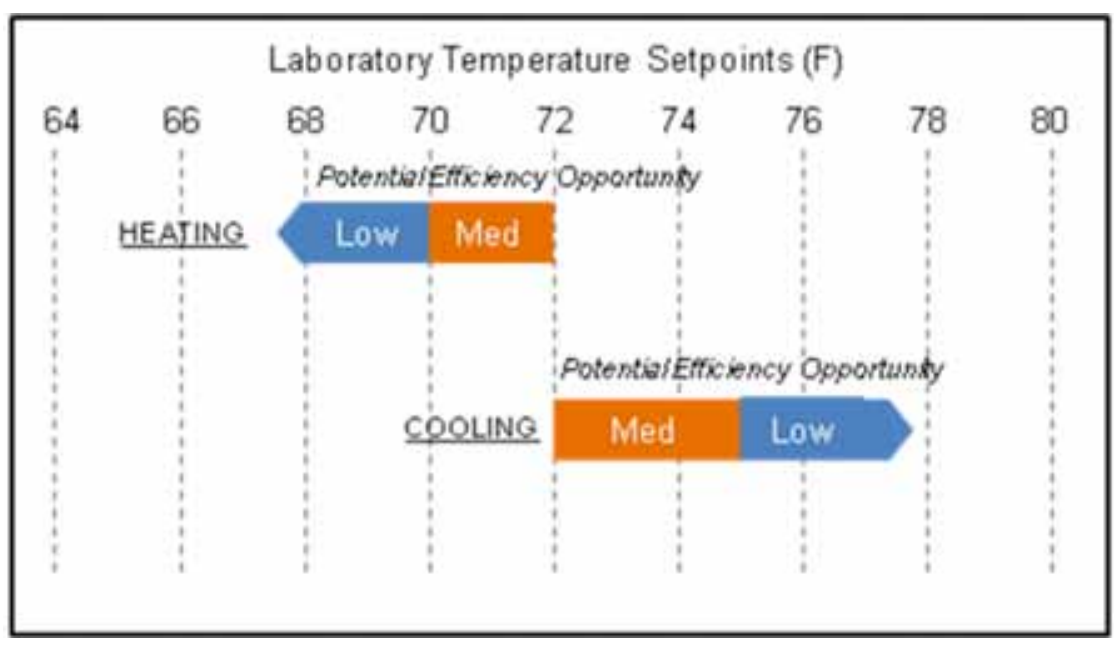

Figure 13. Benchmarks for laboratory temperature setpoints 


\section{Actions Inferred:}

Laboratory users and planners sometimes call for tight ranges based on laboratory function, without evaluating whether these are actually required. Tight ranges can increase energy use due to reheat and humidification. It is recommended that tolerances tighter than those required for human comfort (e.g. based on ASHRAE Standard 55), be carefully evaluated and explicitly justified.

\section{T2: Lab Humidity Setpoint Range}

\section{Description:}

This metric is the actively controlled range of relative humidity.

Units: \%

T1: dT3-dT4 (range)

where:

dT3: Minimum relative humidity setpoint (\%)

dT4: Maximum relative humidity setpoint $(\%)$

See section 8 for more information on the data items.

\section{Benchmarks:}

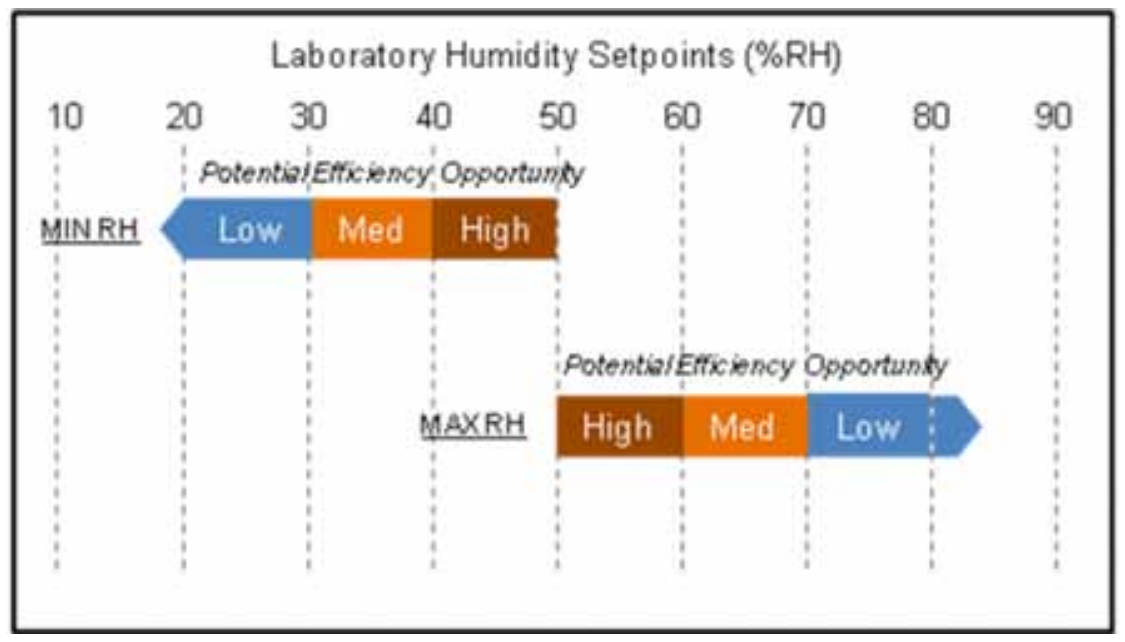

Figure 14. Benchmarks for laboratory relative humidity setpoints

\section{Actions Inferred:}

Laboratory users and planners sometimes call for tight ranges based on laboratory function, without evaluating whether these are actually required. Tight ranges can increase energy use due to reheat and humidification. It is recommended that tolerances tighter than those required for human comfort (e.g. based on ASHRAE Standard 55), be carefully evaluated and explicitly justified. 


\section{Description:}

This metric characterizes the overall efficiency of the cooling system (including chillers, pumps, cooling towers) in terms of energy input per unit of cooling output.

Units: $\mathrm{kW} /$ ton $[\mathrm{kWe} / \mathrm{kWt}]$

$\mathrm{T} 3=\mathrm{dT} 5 \div \mathrm{dT} 6$

where:

dT5: Cooling Plant Annual Energy Use (kWh)

dT6: Cooling Plant Annual Load Served (ton-hrs)

See section 8 for more information on the data items.

Benchmarks:

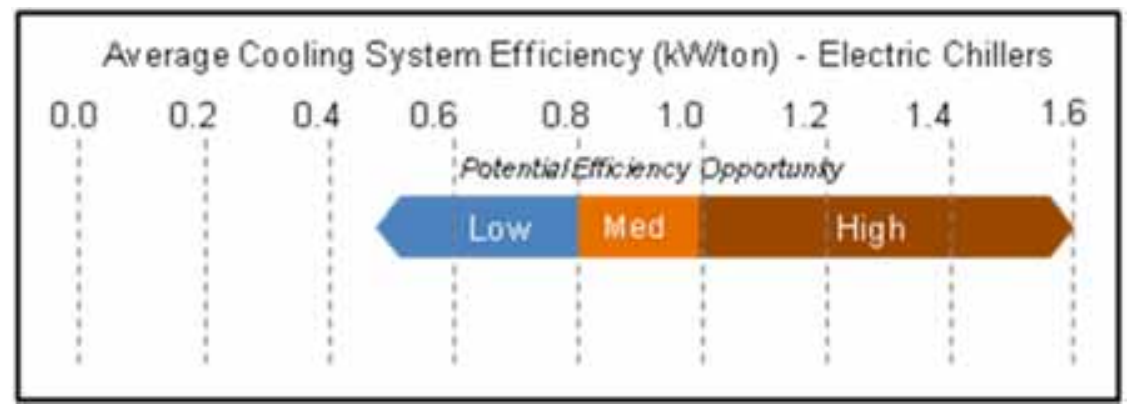

Figure 15. Benchmarks for overall cooling system efficiency for electric chillers

\section{Actions Inferred:}

There are many efficiency actions that can be used to improve the overall efficiency of the chiller plant. These include:

- Modularization

- High efficiency chillers

- All-variable-speed system

- Premium efficiency motors

- Increased chilled water temperature

- Water-side economizer

- Controls optimization (staging, resets, etc.)

\section{Special Considerations:}

Absorption chillers are typically evaluated using coefficient of performance. The efficiency of absorption chillers should not be compared to electric chillers unless primary energy of fuel inputs is considered. 


\section{Description:}

This metric is the ratio of the minimum load (with continuous compressor operation without hot gas bypass or other false loading methods) to design load of the cooling system.

Units: -

$$
\mathrm{T} 4=\mathrm{dT} 7
$$

where:

dT7: Chiller System Minimum Turndown Ratio (-)

See section 8 for more information on the data items.

\section{Benchmarks:}

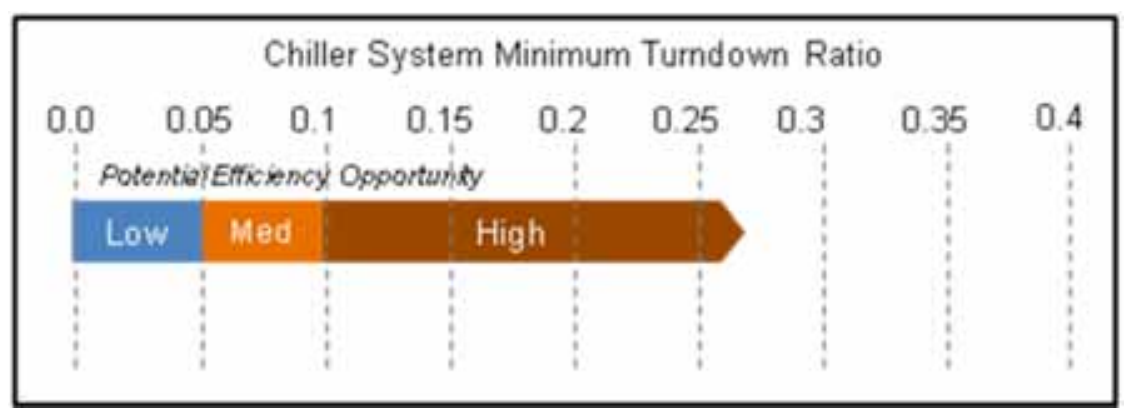

Figure 16. Benchmarks for chiller system minimum turndown ratio

\section{Actions Inferred:}

Laboratory systems are often oversized due to reliability/redundancy requirements, overestimated process loads, or other factors. Even when systems are "right-sized", there are many hours when loads are much lower than peak. In labs with tight humidity control, even lower ratios are warranted, unless alternative dehumidification strategies are adopted. The minimum turn down ratio can be reduced by using a modular chiller plant or a small "pony" chiller for low loads.

\section{T5: Peak Cooling Load Intensity}

\section{Description:}

This metric is the inverse of peak cooling load per unit of gross floor area.

Units: $\mathrm{ft}^{2} /$ ton $\left[\mathrm{m}^{2} /\right.$ ton]

$\mathrm{T} 5=\mathrm{dB} 1 \div \mathrm{dT} 9$

where:

$\mathrm{dB} 1$ : Building Gross Area $\left(\mathrm{ft}^{2}\right)$

dT9: Peak Chiller Load (tons)

See section 8 for more information on the data items. 


\section{Benchmarks:}

This metric can be benchmarked relative to peer buildings in the Labs 21 database. The peer group should be a sub set of buildings in the Labs 21 database that have similar characteristics in terms of climate zone, lab type, and lab area ratio. The Labs 21 tool provides guidance on selecting a peer group.

Note: At the time this guide was published, the Labs21 database did not have adequate data for New York State climate zones.

\section{Actions Inferred:}

Reducing peak cooling loads may afford opportunities to "right-size" the cooling plant and improve part load efficiency. Measures to reduce peak cooling load include: lowering ventilation requirements, controlling solar loads, and reducing plug loads and lighting loads at peak conditions.

\section{Special Considerations:}

The diagnostic ability of this metric is limited by the degree to which the peer group of buildings has similar characteristics. While the Labs 21 benchmarking tool allows for simple data filtering of key characteristics (climate zone, lab area ratio, lab type, occupancy hours), there may be other characteristics (e.g. process loads) that cause loads to be higher or lower independent of efficiency. Therefore, this metric is only a coarse screen for cooling load reduction potential.

\section{T6: Cooling System Sizing Factor}

\section{Description:}

This metric is the ratio of the installed cooling capacity to the peak cooling load.

Units: -

$\mathrm{T} 6=\mathrm{dT} 8 \div \mathrm{dT} 9$

where:

dT8: Installed Chiller Capacity (w/o backup) (tons)

dT9: Peak Chiller Load (tons)

See section 8 for more information on the data items

\section{Benchmarks:}

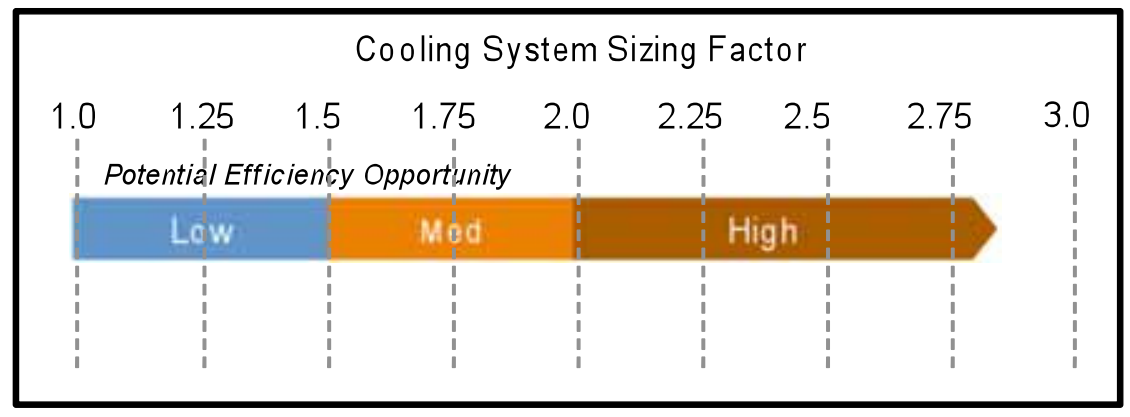

Figure 17. Benchmarks for Cooling System Sizing Factor 


\section{Actions Inferred:}

A high value for this metric indicates the opportunity to "right-size" the cooling plant and improve part load efficiency. Part load efficiency can also be improved by using a modularized plant design.

\section{T7: Chilled Water Loop Temperature Differential}

\section{Description:}

This metric is the difference between the chilled water return and supply temperatures.

Units: $\mathrm{F}[\mathrm{C}]$

$\mathrm{T} 7=\mathrm{dT} 11-\mathrm{dT} 10$

where:

dT11: Chilled Water Return Temperature (F)

dT10: Chilled Water Supply Temperature (F)

See section 8 for more information on the data items.

\section{Benchmarks:}

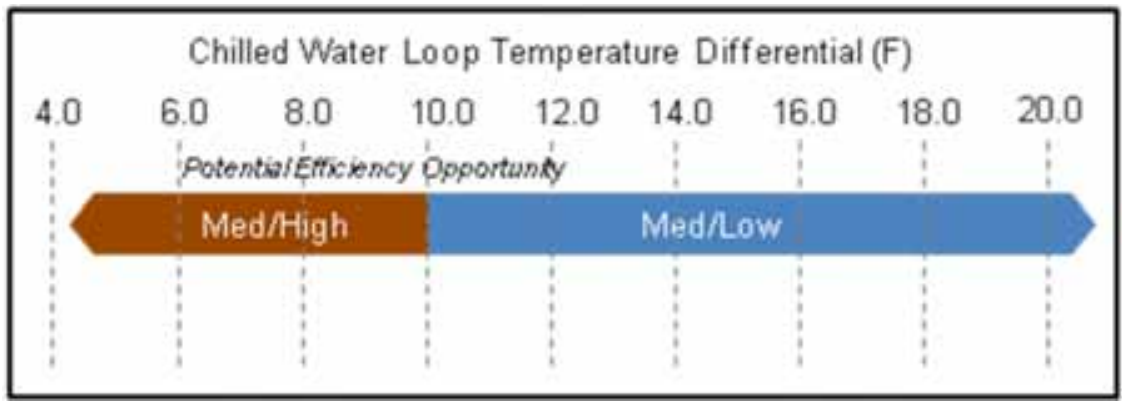

Figure 18. Benchmarks for Chilled Water Loop Temp Differential

\section{Actions Inferred:}

A low value for this metric indicates the opportunity to save energy by:

- reducing chilled water flow, and/or

- increasing chilled water supply temperature.

\section{T8: Cooling System Energy Use Intensity}

\section{Description:}

This metric is the annual cooling system energy use per unit of gross building area.

Units: $\mathrm{kWh} / \mathrm{ft}^{2}\left[\mathrm{kWh} / \mathrm{m}^{2}\right]$

$\mathrm{T} 8=\mathrm{dT} 5 \div \mathrm{dB} 1$

where:

dT5: Cooling Plant Annual Energy Use (kWh)

$\mathrm{dB} 1$ : Building gross area $\left(\mathrm{ft}^{2}\right)$

See section 8 for more information on the data items. 


\section{Benchmarks:}

This metric can be benchmarked relative to peer buildings in the Labs 21 database. The peer group should be a sub set of buildings in the Labs21 database that have similar characteristics in terms of climate zone, lab type, lab area ratio and occupancy hours.

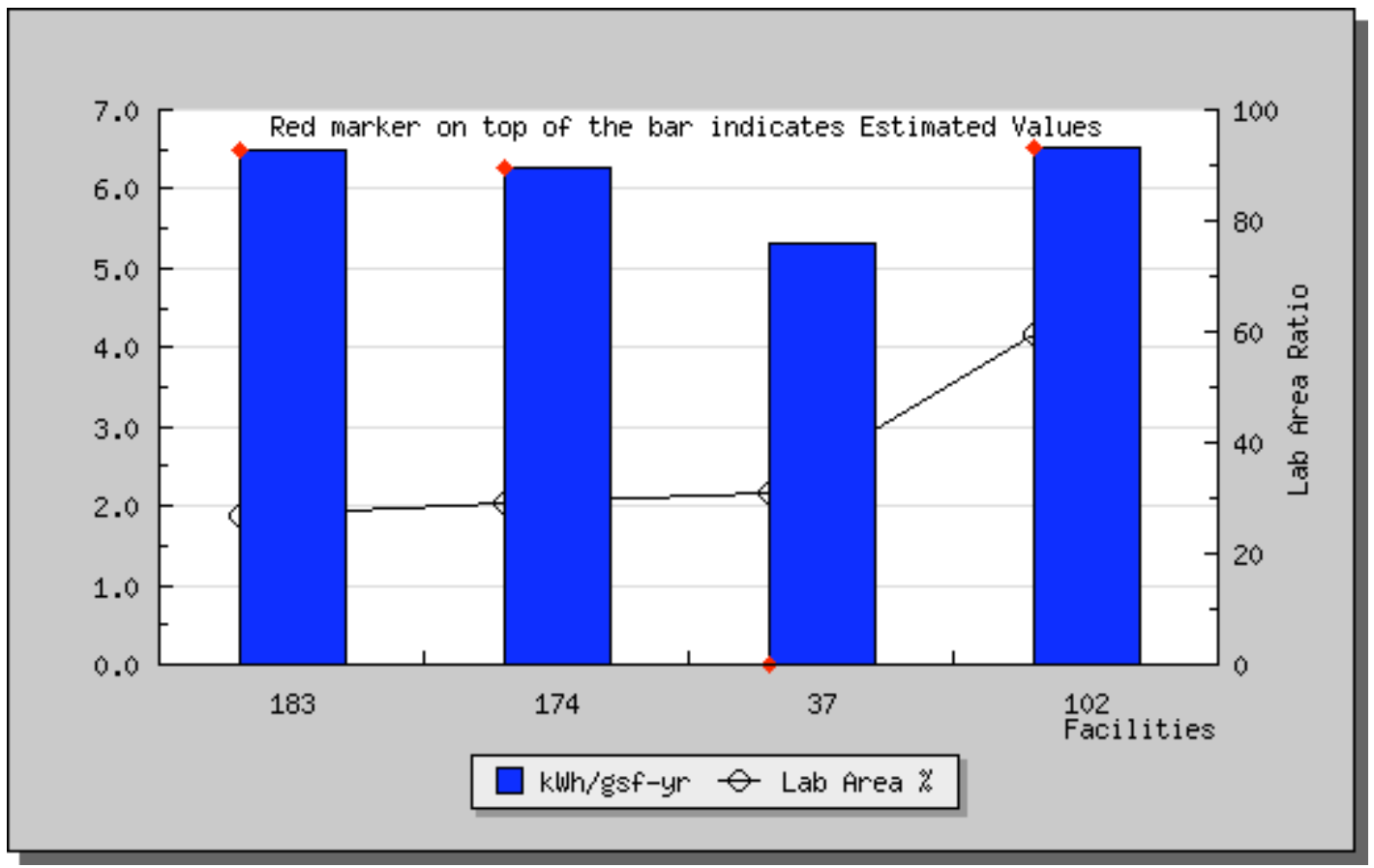

Figure 19. Cooling system energy use intensity for a subset of buildings in the Labs21 database, with the following filters applied: located in climate zone 5A (cool humid); lab type: biological, chemical, chemical/biological; occupancy hours: $<=14$ per typical workday

\section{Actions Inferred:}

This metric provides a measure of overall potential for reducing cooling energy use i.e. higher values relative to the peer group suggest higher potential to reduce energy use and vice versa.

\section{Special Considerations:}

The ability of this metric to identify savings potential is limited by the degree to which the peer group of buildings has similar characteristics. While the Labs21 benchmarking tool allows for simple data filtering of key characteristics (climate zone, lab area ratio, lab type, occupancy hours), there may be other characteristics (e.g. unusual process loads, high hazards requiring higher air change rates) that cause cooling energy use to be higher or lower independent of efficiency.

\section{T9: Heating System Efficiency}

\section{Description:}

This metric characterizes the efficiency of the heating system in terms of energy input per unit of heating output.

Units: \% 
$\mathrm{T} 9=\mathrm{dT} 13 \div \mathrm{dT} 12$

where:

dT13: Heating Plant Annual Load Served (MMBTU)

dT12: Heating Plant Annual Energy Use (MMBTU)

See section 8 for more information on the data items.

Benchmarks:

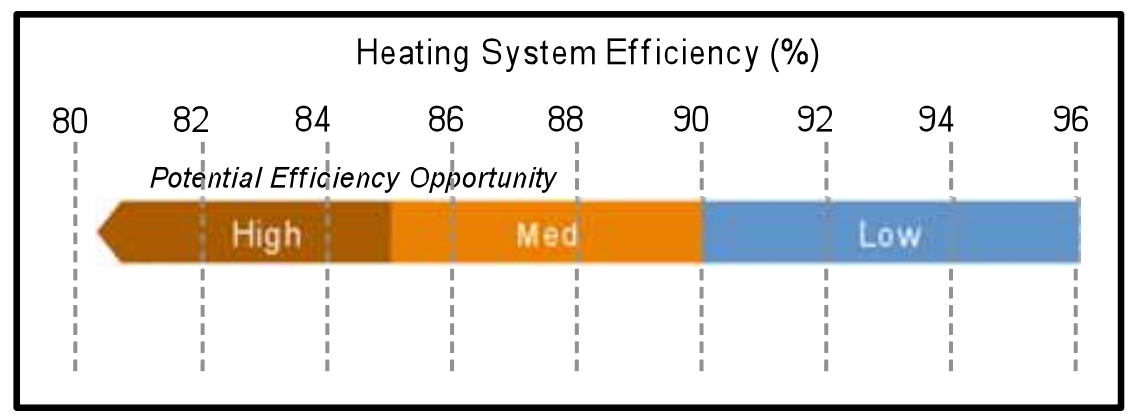

Figure 20. Benchmarks for heating system efficiency

\section{Actions Inferred:}

There are many efficiency actions that can be used to improve the overall efficiency of the heating plant. These include:

- Modularization

- High efficiency boilers

- Lower hot water temperature

- Controls optimization (staging, resets, etc.)

\section{T10: Reheat Energy Use Factor}

\section{Description:}

This metric is the ratio of the reheat energy use to the total space heating energy use.

Units: -

$\mathrm{T} 10=\mathrm{dT} 14 \div \mathrm{dT} 13$

where:

dT14: Reheat Annual Energy Load (MMBTU)

dT13: Heating Plant Annual Load Served (MMBTU)

See section 8 for more information on the data items. 


\section{Benchmarks:}

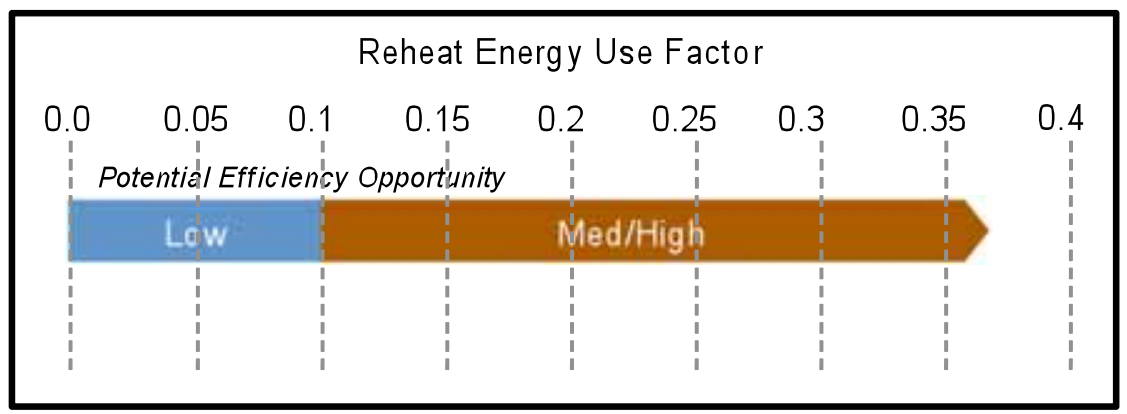

Figure 21. Benchmarks for Reheat Energy Use Factor

\section{Actions Inferred:}

Measures to reduce reheat energy use include:

- Widening temperature and humidity setpoint ranges.

- Recalibration and optimization of controls

- Better matching of loads and cooling capacity.

- Systems that separate thermal conditioning from ventilation requirements (this would be a major retrofit in most existing buildings that have reheat systems)

\section{T11: Heating System Energy Use Intensity}

\section{Description:}

This metric is the annual heating system energy use per unit of gross building area.

Units: $\mathrm{kBTU} / \mathrm{ft}^{2}\left[\mathrm{kWh} / \mathrm{m}^{2}, \mathrm{MJ} / \mathrm{m}^{2}\right]$

$\mathrm{T} 11=\mathrm{dT} 12 * 1000 \div \mathrm{dB} 1$

where:

dT12: Heating Plant Annual Energy Use (MMBTU)

$\mathrm{dB1}$ : Building gross area $\left(\mathrm{ft}^{2}\right)$

See section 8 for more information on the data items.

\section{Benchmarks:}

This metric currently not available in the Labs21 benchmarking tool. This metric can be benchmarked relative to peer buildings that have similar characteristics in terms of climate zone, lab type, lab area ratio and occupancy hours. No benchmarking data are available at the time this guide was published.

\section{Actions Inferred:}

This metric provides a measure of overall potential for reducing heating energy use i.e. higher values relative to the peer group suggest higher potential to reduce energy use and vice versa.

\section{Special Considerations:}

The ability of this metric to identify savings potential is limited by the degree to which the peer group of buildings has similar characteristics. Even within a peer group of similar key 
characteristics (climate zone, lab area ratio, lab type, occupancy hours), there may be other characteristics (e.g. unusual process loads, high hazards requiring higher air change rates) that cause heating energy use to be higher or lower independent of efficiency. 


\section{Plug Load Metrics}

\begin{tabular}{|c|l|c|}
\hline ID & Name & Priority \\
\hline P1 & Laboratory Design Plug-Load Intensity & 1 \\
\hline P2 & Laboratory Actual Plug-Load Intensity & 1 \\
\hline P3 & Laboratory Plug-Load Sizing Factor (design/measured) & 1 \\
\hline P4 & Total Plug Load Energy Intensity & 3 \\
\hline
\end{tabular}

\section{P1: Laboratory Design Plug-Load Intensity}

\section{Description:}

This metric is the design value for equipment load per unit of net laboratory area.

Units: $\mathrm{W} / \mathrm{ft}^{2}\left[\mathrm{~W} / \mathrm{m}^{2}\right]$

$$
\mathrm{P} 1=\mathrm{dP} 2 * 1000 \div \mathrm{dB} 2
$$

where:

dP2: Laboratory Plug Load: Design Peak (kW)

$\mathrm{dB} 2$ : Laboratory area $\left(\right.$ net $\left.\mathrm{ft}^{2}\right)$

See section 8 for more information on the data items.

\section{Benchmarks:}

See metric P2

\section{Actions Inferred:}

See metric P3

\section{Actions Inferred:}

Note that the assumption for electrical system design is usually higher than that for HVAC system design. This metric refers to the plug load intensity used for HVAC design.

\section{P2: Laboratory Actual Plug-Load Intensity}

\section{Description:}

This metric is the actual value for peak equipment load per unit of net laboratory area.

Units: $\mathrm{W} / \mathrm{ft}^{2}\left[\mathrm{~W} / \mathrm{m}^{2}\right]$

$$
\mathrm{P} 1=\mathrm{dP} 1 * 1000 \div \mathrm{dB} 2
$$

where:

dP1: Laboratory Plug Load: Design Peak (kW)

$\mathrm{dB} 2$ : Laboratory area (net $\mathrm{ft}^{2}$ )

See section 8 for more information on the data items. 


\section{Benchmarks:}

The benchmarks for this metric are driven by the type of processes and equipment in the laboratory. The benchmarks below provide a range of measured values in various types of laboratories. These ranges are based on measurements in about 40 laboratories, as documented in a Labs21 technical bulletin (http://www.labs21century.gov/pdf/ bp_equipment_508.pdf).

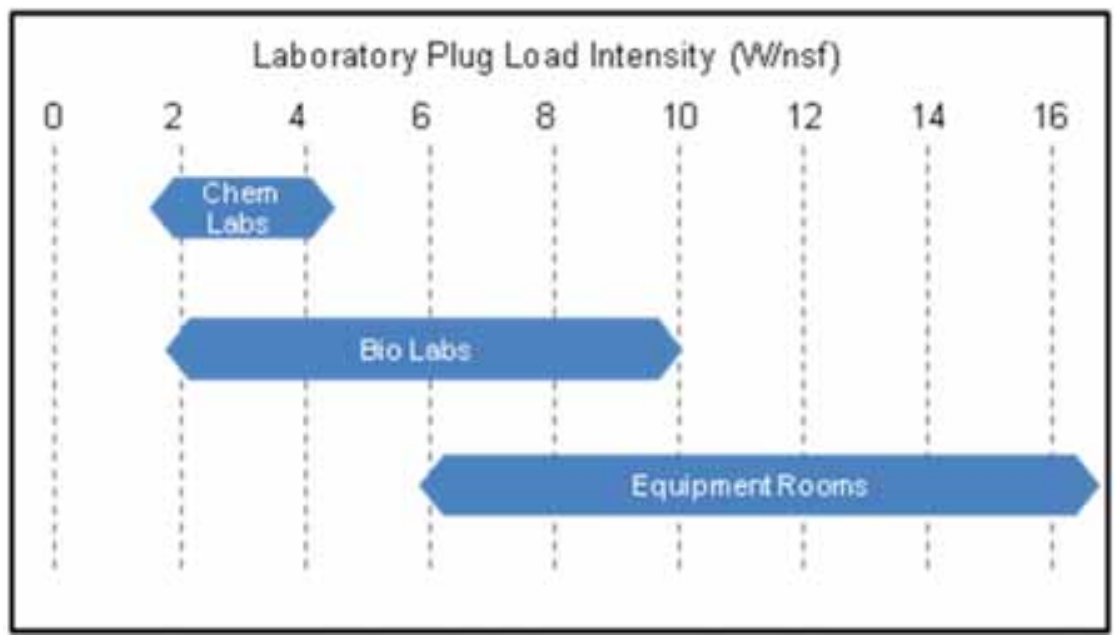

Figure 22. $\quad$ Range of peak plug loads measured in different types of laboratories (based on Labs 21 technical bulletin (http://www.labs21century.gov/pdf/bp_equipment_508.pdf).

\section{Actions Inferred:}

Plug load is driven by the equipment and processes in the laboratory. A high value of for this metric may suggest the following actions:

- Conducting a usage audit to identify equipment that may be turned off or retired.

- Procuring more energy efficiency equipment.

\section{P3: Laboratory Plug-Load Sizing Factor}

\section{Description:}

This metric is the ratio of the design value of the equipment load to the peak actual equipment load in the laboratory spaces.

Units: -

$\mathrm{P} 3=\mathrm{dP} 2 \div \mathrm{dP} 1$

where:

dP2: Laboratory Plug Load: Design Peak (kW)

dP1: Laboratory Plug Load: Actual Peak (kW)

See section 8 for more information on the data items. 


\section{Benchmarks:}

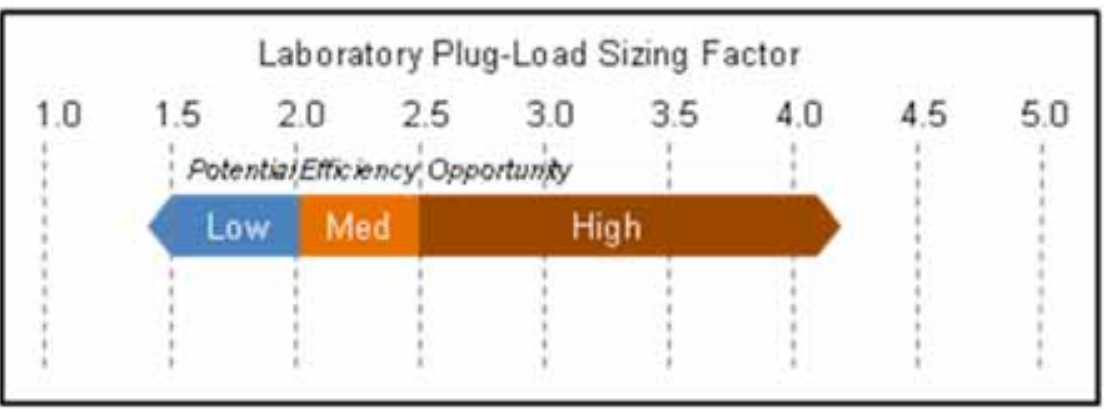

Figure 23. Benchmarks for Laboratory Plug Load Sizing Factor

\section{Actions Inferred:}

A high value for this metric indicates the opportunity to "right-size" the HVAC systems and improve part load efficiency. Equipment loads in laboratories are frequently overestimated because designers often use estimates based on "nameplate" data, and design assumptions of high utilization. This results in oversized HVAC systems, increased initial construction costs, and increased energy use due to inefficiencies at low part-load operation

\section{Special Considerations:}

The sizing ratio (design/measured) is driven by context specific factors such as reliability and flexibility. The benchmarks provided above are a general guideline. In some situations, unusual requirements for flexibility and reliability may result in a high sizing factor.

\section{P4: Total Plug Load Energy Use Intensity}

\section{Description:}

This metric is the annual equipment load energy use per unit of gross building area.

Units: $\mathrm{kWh} / \mathrm{ft}^{2}\left[\mathrm{kWh} / \mathrm{m}^{2}\right]$

$$
\mathrm{P} 4=\mathrm{dP} 3 \div \mathrm{dB} 1
$$

where:

dP3: Plug Load Annual Energy Use (kWh)

$\mathrm{dB} 1$ : Building gross area $\left(\mathrm{ft}^{2}\right)$

See section 8 for more information on the data items.

\section{Benchmarks:}

This metric can be benchmarked relative to peer buildings in the Labs 21 database. The peer group should be a sub set of buildings in the Labs 21 database that have similar characteristics in terms of lab type, lab area ratio and occupancy hours. 


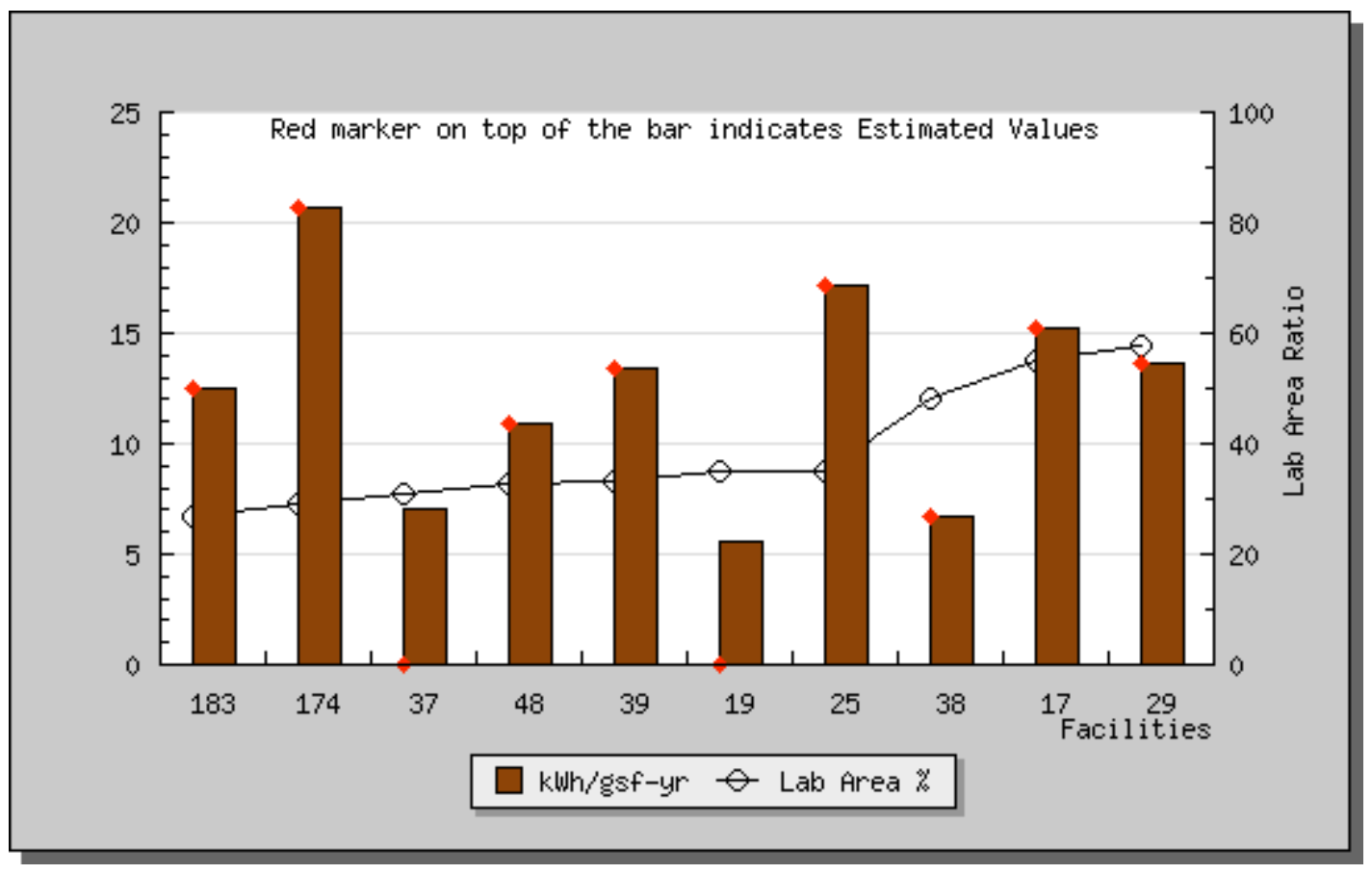

Figure 24. Plug load energy use intensity for a subset of buildings in the Labs21 database, with the following filters applied: lab type: biological, chemical, chemical/biological; occupancy hours: $<=14$ per typical workday

\section{Actions Inferred:}

This metric provides a measure of overall potential for reducing plug load energy use i.e. higher values relative to the peer group suggest higher potential to reduce energy use and vice versa. Some of the actions to reduce plug load energy use include:

- Turning off equipment while not in use

- Conducting a usage audit to identify equipment that may be turned off or retired.

- Procuring more energy efficiency equipment.

\section{Special Considerations:}

The ability of this metric to identify savings potential is limited by the degree to which the peer group of buildings has similar characteristics. While the Labs21 benchmarking tool allows for simple data filtering of key characteristics (lab area ratio, lab type, occupancy hours), there may be other characteristics (e.g. unusual equipment or processes) that cause plug load energy use to be higher or lower independent of efficiency. 


\section{Lighting Metrics}

\begin{tabular}{|c|l|c|}
\hline ID & Name & Priority \\
\hline L1 & Laboratory Task Illuminance & 1 \\
\hline L2 & Laboratory Ambient Illuminance & 1 \\
\hline L3 & Laboratory Lighting Installed Power Intensity & 1 \\
\hline L4 & Laboratory Lighting Zone Size & 2 \\
\hline L5 & Lighting Energy Use Intensity & 3 \\
\hline
\end{tabular}

\section{L1: Laboratory Task Illuminance}

\section{Description:}

This metric is the measured task illuminance level for the laboratory spaces. It is typically measured at the bench-top.

Units: fc [lux]

$$
\mathrm{L} 1=\mathrm{dL} 1
$$

where:

dL1: Laboratory Task Illuminance (fc)

See section 8 for more information on the data items.

\section{Benchmarks:}

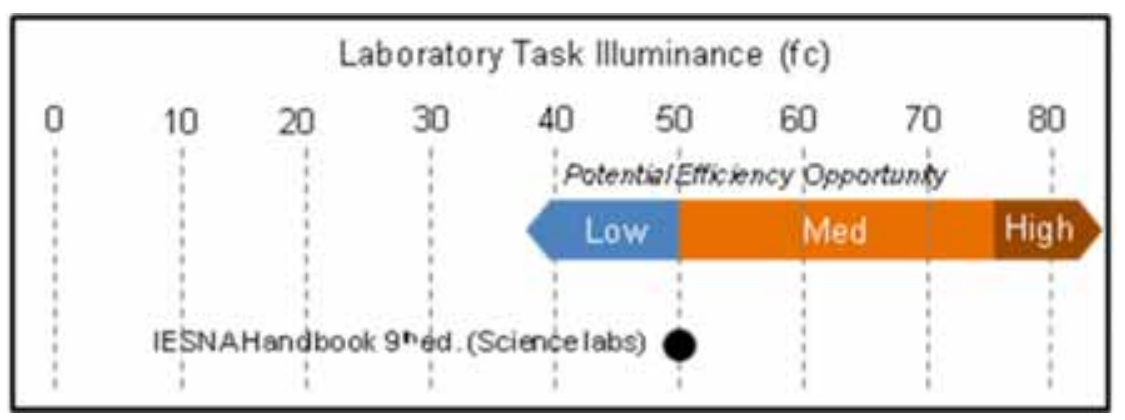

Figure 25. Benchmarks for Laboratory Task Illuminance

\section{Actions Inferred:}

A high value for this metric indicates the opportunity to "right-size" the illuminance levels and reduce lighting energy use. Lighting systems are sometimes over-sized, resulting in more illuminance than required for the task. Illuminance levels can be reduced by de-lamping existing lighting fixtures, or by retrofitting and reconfiguring the lighting fixtures.

\section{Special Considerations:}

Some laboratory tasks may require higher than normal task illuminance levels and the benchmarks indicated above may need to be adjusted upward. However, the higher levels of illuminance are only needed for the specific areas where these tasks are being performed - 
and should not be applied to other areas of the laboratory for which normal task illuminance levels are adequate.

\section{L2: Laboratory Ambient Illuminance}

\section{Description:}

This metric is the measured task illuminance level for the laboratory spaces. It is typically measured at the bench-top.

Units: fc [lux]

$\mathrm{L} 2=\mathrm{dL} 2$

where:

dL2: Laboratory Ambient Illuminance (fc)

See section 8 for more information on the data items.

\section{Benchmarks:}

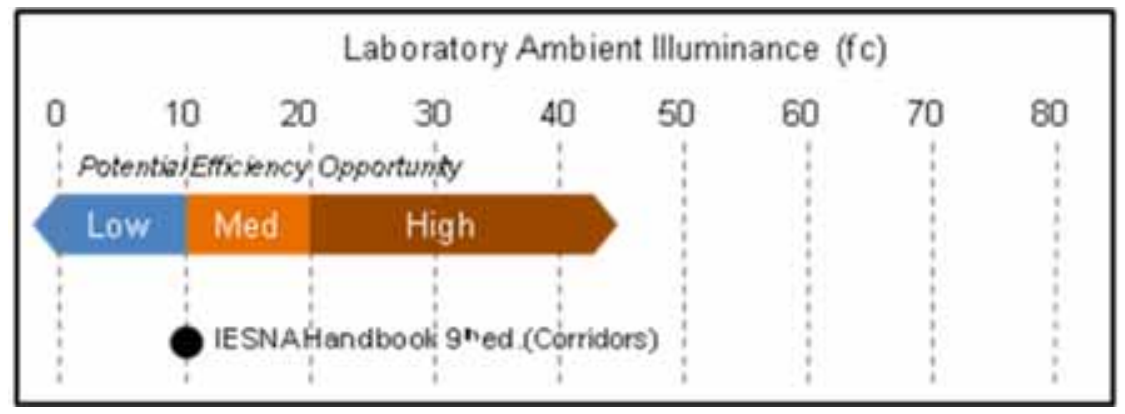

Figure 26. Benchmarks for Laboratory Ambient Illuminance

\section{Actions Inferred:}

A high value for this metric indicates the opportunity to "right-size" the ambient illuminance levels and reduce lighting energy use (assuming that there are separate task and ambient lighting systems). Illuminance levels can be reduced by de-lamping existing lighting fixtures, or by retrofitting and reconfiguring the lighting fixtures.

\section{L3: Laboratory Lighting Installed Power Intensity}

\section{Description:}

This metric is the installed lighting power per unit of net laboratory area.

Units: $\mathrm{W} / \mathrm{ft}^{2}\left[\mathrm{~W} / \mathrm{m}^{2}\right]$

$\mathrm{L} 3=\mathrm{dL} 3 * 1000 \div \mathrm{dB} 2$

where:

dP1: Laboratory Lighting Installed Power $(\mathrm{kW})$

$\mathrm{dB} 2$ : Laboratory area $\left(\right.$ net $\left.\mathrm{ft}^{2}\right)$ 
See section 8 for more information on the data items

Benchmarks:

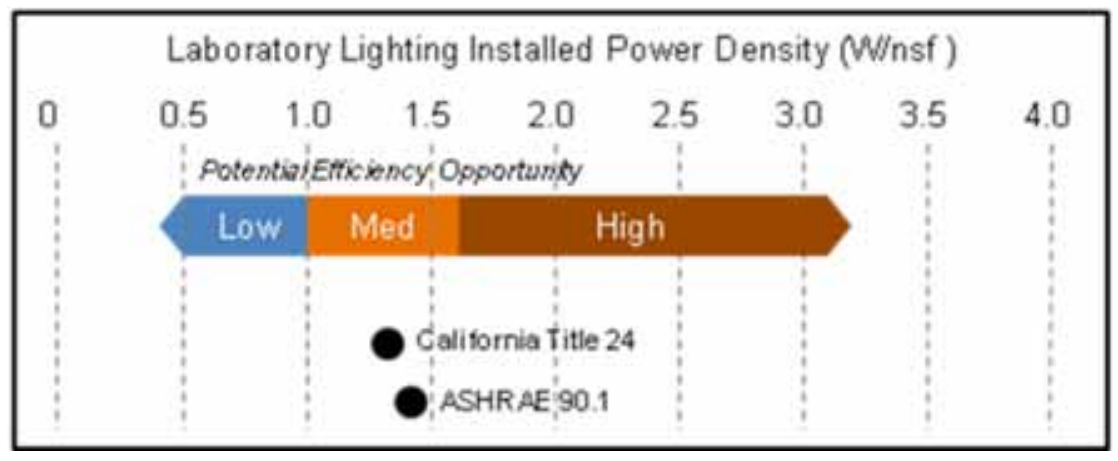

Figure 27. Benchmarks for Laboratory Lighting Installed Power Density.

\section{Actions Inferred:}

A high value for this metric indicates the opportunity to improve the installed lighting efficiency through retrofits including:

- More efficient lamps and ballasts

- More effective fixtures and lighting system configuration.

\section{L4: Laboratory Lighting Zone Size}

\section{Description:}

This metric is the average size of the lighting control zone in the laboratory

Units: $\mathrm{ft}^{2}\left[\mathrm{~m}^{2}\right]$

$\mathrm{L} 4=\mathrm{dL} 4$

where:

dL4: Laboratory Lighting Zone Size $\left(\mathrm{ft}^{2}\right)$

See section 8 for more information on the data items.

\section{Benchmarks:}

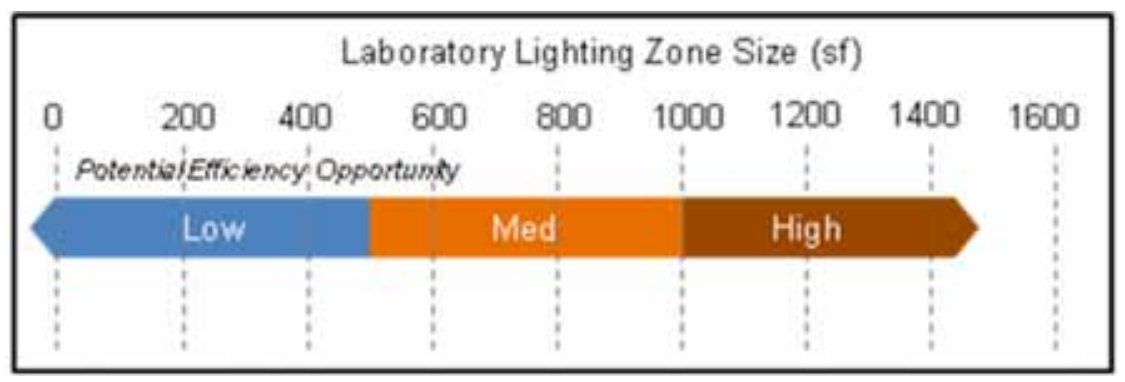

Figure 28. Benchmarks for Laboratory Lighting Zone Size 


\section{Actions Inferred:}

A high value for this metric indicates the opportunity to increase the number of lighting control zones (and thereby reduce zone size). This will permit more lights to be turned off during periods of low occupancy.

\section{L5: Lighting Energy Use Intensity}

\section{Description:}

This metric is the annual lighting energy use per unit of gross building area.

Units: $\mathrm{kWh} / \mathrm{ft}^{2}\left[\mathrm{kWh} / \mathrm{m}^{2}\right]$

$$
\mathrm{L} 5=\mathrm{dL} 5 \div \mathrm{dB} 1
$$

where:

dP3: Lighting Annual Energy Use (kWh)

$\mathrm{dB} 1$ : Building gross area $\left(\mathrm{ft}^{2}\right)$

See section 8 for more information on the data items.

\section{Benchmarks:}

This metric can be benchmarked relative to peer buildings in the Labs 21 database. The peer group should be a sub set of buildings in the Labs 21 database that have similar characteristics in terms of lab type, lab area ratio and occupancy hours.

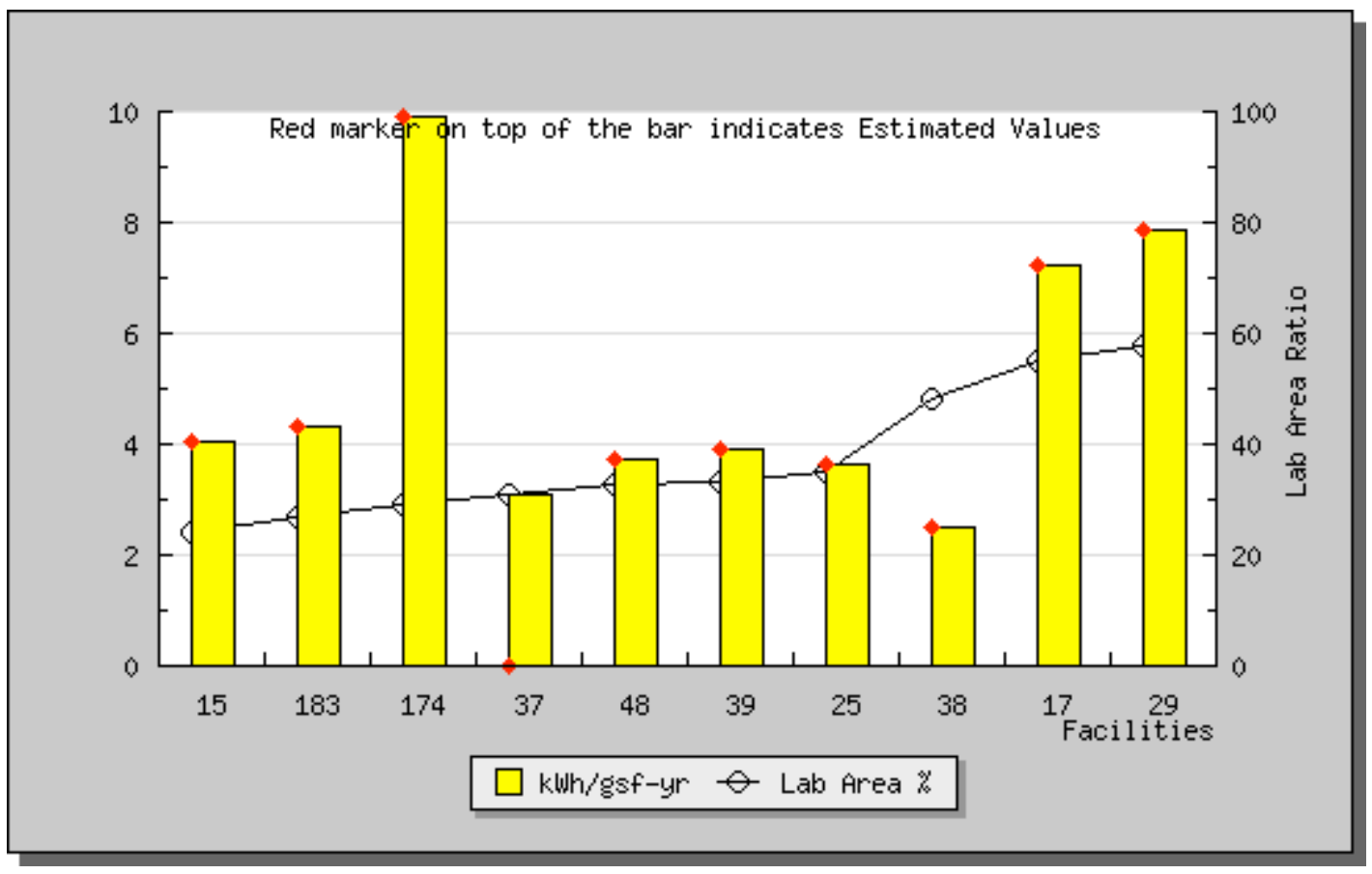

Figure 29. Lighting energy use intensity for a subset of buildings in the Labs21 database, with the following filters applied: lab type: biological, chemical, chemical/biological; occupancy hours: $<=14$ per typical workday 
Actions Inferred:

This metric provides a measure of overall potential for reducing lighting energy use i.e. higher values relative to the peer group suggest higher potential to reduce energy use and vice versa. Some of the actions to reduce lighting energy use include:

- More efficient lamps and ballasts

- More effective fixtures and lighting system configuration.

- Occupancy-based lighting control

- Daylight-based lighting control

Special Considerations:

The ability of this metric to identify savings potential is limited by the degree to which the peer group of buildings has similar characteristics. While the Labs 21 benchmarking tool allows for simple data filtering of key characteristics (lab area ratio, lab type, occupancy hours), there may be other characteristics (e.g. unusual lighting requirements for certain labs) that cause lighting energy use to be higher or lower independent of efficiency. 


\section{Data Required for Performance Metrics}

The table below lists the data required for the performance metrics described in sections 3-7.

\begin{tabular}{|c|c|c|}
\hline ID & Data Items & Measurement/Calculation Guidance \\
\hline \multicolumn{3}{|c|}{ General Building Data } \\
\hline $\mathrm{dB} 1$ & Building Gross Area & \\
\hline $\mathrm{dB2}$ & Laboratory Area & Area requiring $100 \%$ outside air. \\
\hline dB3 & Laboratory Volume & $\begin{array}{l}\text { Can be calculated from area using average ceiling } \\
\text { height. }\end{array}$ \\
\hline $\mathrm{dB} 4$ & Building Occupant Count & \\
\hline $\mathrm{dB5}$ & Laboratory Occupant Count & \\
\hline dB6 & Fumehood Count & \\
\hline $\mathrm{dB} 7$ & Fumehood Total Length & \\
\hline $\mathrm{dB8}$ & Typical Daily Occupied Hours (weekday) & Do not include hours with very low occupancy. \\
\hline dB9 & Year of Construction (or major renovation) & \\
\hline \multicolumn{3}{|c|}{ Building Energy Data } \\
\hline $\mathrm{dE} 1$ & Annual Electrical Energy Use & Meter data or utility bills. \\
\hline dE2 & Annual Natural Gas Energy Use & Meter data or utility bills. \\
\hline dE3 & Annual Fuel Oil Energy Use & Meter data or utility bills. \\
\hline $\mathrm{dE} 4$ & Annual Other Fuel Energy Use & Meter data or utility bills. \\
\hline dE5 & Annual District Steam Energy Use & Meter data or utility bills. \\
\hline $\mathrm{dE} 6$ & Annual District Hot Water Energy Use & Meter data or utility bills. \\
\hline $\mathrm{dE7}$ & Annual District Chilled Water Energy Use & Meter data or utility bills. \\
\hline $\mathrm{dE8}$ & Annual Energy Cost & Meter data or utility bills. \\
\hline dE9 & Peak Electrical Demand & Meter data or utility bills. \\
\hline \multicolumn{3}{|c|}{ Ventilation Data } \\
\hline $\mathrm{dV} 1$ & Laboratory Supply Airflow Min & \\
\hline $\mathrm{dV} 2$ & Supply Side Fan Peak Power & Use design data if measured data not available. \\
\hline dV3 & Exhaust Side Fan Peak Power & Use design data if measured data not available. \\
\hline $\mathrm{dV4}$ & Supply Side Fan Peak Airflow & Use design data if measured data not available. \\
\hline $\mathrm{dV5}$ & Exhaust Side Fan Peak Airflow & Use design data if measured data not available. \\
\hline $\mathrm{dV6}$ & Supply-side Pressure Drop & Use design data if measured data not available. \\
\hline $\mathrm{dV7}$ & Exhaust-side Pressure Drop & Use design data if measured data not available. \\
\hline $\mathrm{dV} 8$ & Fumehood Average Airflow & Average over 1 year or representative period. \\
\hline $\mathrm{dV9}$ & Fumehood Minimum Airflow & Airflow when sash is closed. \\
\hline $\mathrm{dV} 10$ & Ventilation Annual Energy Use & \\
\hline \multicolumn{3}{|c|}{ Cooling \& Heating Data } \\
\hline $\mathrm{dT1}$ & Heating Setpoint & \\
\hline dT2 & Cooling Setpoint & \\
\hline dT3 & Minimum Humidity Setpoint & \\
\hline dT4 & Maximum Humidity Setpoint & \\
\hline dT5 & Cooling Plant Annual Energy Use & Includes chillers, pumps, cooling towers. \\
\hline dT6 & Cooling Plant Annual Load Served & $\begin{array}{l}\text { If load is not directly measured, it can be calculated } \\
\text { from flow rate and supply and return temperatures. }\end{array}$ \\
\hline dT7 & Chiller System Minimum Turndown Ratio & Maximum turndown without hot gas bypass. \\
\hline
\end{tabular}




\begin{tabular}{|l|l|l|} 
ID & Data Items & Measurement/Calculation Guidance \\
\hline dT8 & Installed Chiller Capacity (w/o backup) & Rated capacity \\
\hline dT9 & Peak Chiller Load & Peak over one year \\
\hline dT10 & Chilled Water Supply Temperature & Average over 1 year or representative period \\
\hline dT11 & Chilled Water Return Temperature & Average over 1 year or representative period \\
\hline dT12 & Heating Plant Annual Energy Use & \\
\hline dT13 & Heating Plant Annual Load Served & $\begin{array}{l}\text { If load is not directly measured, it can be calculated } \\
\text { from flow rate and supply and return temperatures }\end{array}$ \\
\hline dT14 & Reheat Annual Energy Load & Energy used by reheat coils to reheat chilled air. \\
\hline Plug Load Data & \\
\hline dP1 & Laboratory Plug Load: Actual Peak & Can be measured at the panel level \\
\hline dP2 & Laboratory Plug Load: Design Peak & \\
\hline dP3 & Plug Load Annual Energy Use & \\
\hline Lighting Data & \\
\hline dL1 & Laboratory Task Illuminance & Benchtop illuminance \\
\hline dL2 & Laboratory Ambient Illuminance & Illuminance in walkways \\
\hline dL3 & Laboratory Lighting Installed Power & Can be estimated from lamp specifications \\
\hline dL4 & Laboratory Lighting Zone Size & Can be estimated from switches \\
\hline dL5 & Lighting Annual Energy Use & \\
\hline
\end{tabular}




\section{References}

ASHRAE/ANSI/IESNA Standard 90.1: Energy Standard for Buildings except Low-Rise Residential Buildings . American Society of Heating, Refrigerating, and AirConditioning Engineers. Atlanta, Georgia.

California Title 24 Non-residential Compliance Manual. Available at: http://www.energy.ca.gov/title24/

Efficient Electrical Lighting for Laboratories. Published by Labs21, October 2006. Available on the web at: www.labs21century.gov. LBNL-60606

IESNA Lighting Handbook, Reference and Application. 9th Edition. Rea, M. (ed). Illuminating Engineering Society of North America. 2000.

Mathew, P, D. Sartor, S. Greenberg, P. Rumsey, J. Weale. "Laboratory Performance: Metrics for Energy Efficiency," ASHRAE Journal, Vol.50, No.4, April 2008. American Society of Heating Refrigerating and Air conditioning Engineers.

Mathew, P., S. Greenberg, D. Frenze, M. Morehead, D. Sartor, W. Starr. "Right-sizing Laboratory HVAC systems - Part 1," HPAC Engineering, September 2005. LBNL58497

Mathew, P., S. Greenberg, D. Frenze, M. Morehead, D. Sartor, W. Starr. "Right-sizing Laboratory HVAC systems - Part 2," HPAC Engineering, October 2005. LBNL-58497

McIntosh, I. B. D., C. B. Dorgan, C. E. Dorgan [2001]. ASHRAE Laboratory Design Guide, American Society of Heating, Refrigerating, and Air-Conditioning Engineers. Atlanta GA.

Measured Peak Equipment Loads in Laboratories. Labs21 Technical Bulletin. Published by Labs21, September 2007. Available on the web at: www.labs21century.gov. LBNL63428

NFPA-45-2004. National Fire Protection Association.

Optimizing Ventilation Rates in Laboratories. Draft Best Practice Guide available from Labs21. (Contact GCBell@lbl.gov)

OSHA 29 CFR 1919-1450 Appendix C. 1990. Occupational Safety and Health Administration

Weale, P. Rumsey, D. Sartor, L. E. Lock, "Laboratory Low-Pressure Drop Design," ASHRAE Journal, August 2002 